\title{
The Efficiency of Arbuscular Mycorrhizal Fungi in Promoting Alfalfa Growth in Acid Soils
}

\author{
Lei Huang ${ }^{1}$, Yuji $\mathrm{He}^{1} \&$ Yanjun Guo ${ }^{1}$ \\ ${ }^{1}$ College of Agronomy and Biotechnology, Southwest University, Chongqing, China \\ Correspondence: Yanjun Guo, College of Agronomy and Biotechnology, Southwest University, Chongqing, \\ 400716, China. Tel: 86-23-6825-1264. E-mail: qhgyj@126.com
}

\author{
Received: February 7, $2017 \quad$ Accepted: March 1, $2017 \quad$ Online Published: March 15, 2017 \\ doi:10.5539/jas.v9n4p186 URL: https://doi.org/10.5539/jas.v9n4p186
}

The research is financed by the National Key Basic Research Program of China (2014CB138806) and the Fundamental Research Funds for the Central Universities (XDJK2014B002).

\begin{abstract}
High concentrations of soil $\mathrm{Al}^{3+}$ in acid soil severely influence the growth of Medicago sativa (alfalfa). The objective of the current study was to analyze whether Arbuscular Mycorrhizal Fungi (AMF) inoculation could improve alfalfa growth in acid soils. A two-way completely randomized factorial design was employed for $M$. sativa and M. lupulina (black medick) with two inoculations (rhizobia and AMF) and three $\mathrm{Al}^{3+}$ levels, and replicated four times. The soil $\mathrm{Al}^{3+}$ levels were adjusted to $900 \mathrm{mg} / \mathrm{kg}, 1000 \mathrm{mg} / \mathrm{kg}$ and $1100 \mathrm{mg} / \mathrm{kg}$. Spores of AMF were isolated directly from rhizosphere soils of black medick. The rhizobia were isolated from root nodules in fields separately from two plant species. At each $\mathrm{Al}^{3+}$ level, there were four inoculations, non-inoculation, AMF solely, rhizobia solely and dual-inoculation with $\mathrm{AMF}$ and rhizobia. Soil $\mathrm{Al}^{3+}$ concentration significantly limited above- and below-ground growth of both alfalfa and black medick, reducing plant height, branching number, shoot and root weight, and root length, surface area and volume. Compared to rhizobia, AMF showed a higher tolerance to soil $\mathrm{Al}^{3+}$. AMF inoculation increased the shoot and root weight of both plant species under most circumstances. Overall, AMF colonization had a trend in increasing the contents of phosphorus in both plant species at all $\mathrm{Al}^{3+}$ concentrations but not nitrogen and potassium. Dual inoculation significantly increased nodulation ability, enabling both plant species to form nodules at 900 and $1000 \mathrm{mg} / \mathrm{kg} \mathrm{Al}^{3+}$. Though the soil $\mathrm{Al}^{3+}$ concentration influenced the efficiency of AMF inoculation, AMF inoculation improved nodulation, increased plant growth and nutrient uptake, suggesting that it was an alternative way in improving alfalfa growth in acid soils.
\end{abstract}

Keywords: acid soil, aluminum, arbuscular mycorrhizal fungi (AMF), Medicago lupulina, Medicago sativa

\section{Introduction}

Medicago sativa L. (alfalfa), a perennial legume crop, is widely grown in temperate and subtropical regions all over the world for its high feeding value, good palatability, great adaptability, and high yield. With the increasing needs from dairy and beef production, alfalfa plantation area has enlarged from northern China to southern china, where about $21 \%$ of the arable land is acid soils, approximately reaching 2.03 million $\mathrm{km}^{2}$ ( $\mathrm{Shi}, \mathrm{Li}, \mathrm{Xu}$, \& Qian, 2016). However, it is generally believed that optimum alfalfa yields are associated with a soil $\mathrm{pH}$ in the range of 6.5 to 7.5. Soil acidity has become one of the limiting factors in planting alfalfa in the South of China (Guo, Ni, Yuan, \& Huang, 2009). With the reduced $\mathrm{pH}$ levels in acid soils, alfalfa yield declines rapidly (Undersander et al., 1991), so do the nodulation, leaf retention, leaf to stem ratio, and crude protein content (Grewal \& Williams, 2003).

Among the factors decreasing soil fertilities in acid soil, aluminum (Al) toxicity has been regarded as the main factor limiting crop yields (Foy, 1988). In neutral or alkaline soil solution, Al is present as harmless oxides and aluminosilicates (Martens, 2001). However, in soils with $\mathrm{pH}$ below 5.5, the solubility of aluminum increases greatly and is released into the soil solution in the form of toxic ions to plants $\left[\mathrm{Al}(\mathrm{OH})^{2+}, \mathrm{Al}(\mathrm{OH})^{2+}, \mathrm{Al}^{3+}\right.$ and $\mathrm{Al}\left(\mathrm{H}_{2} \mathrm{O}\right)_{6}{ }^{3+}$ ] (Kochian, Piñeros, \& Hoekenga, 2004; Rouphael, Cardarelli, \& Colla, 2015). Increased concentrations of $\mathrm{Al}^{3+}$ caused damage to the root tip, leading to the inhibition of root growth, and ultimately 
limiting the plants from adsorbing nutrients and water from soil solutions (Langer, Cea, Curaqueo, \& Borie, 2009). For example, high concentrations of $\mathrm{Al}^{3+}$ reduced the absorption of $\mathrm{Ca}^{2+}, \mathrm{K}^{+}, \mathrm{PO}_{4}{ }^{3-}$ and other essential nutrient elements by crops (Talor, 1988). $\mathrm{Al}^{3+}$ reduced the availability of inorganic phosphorus by inducing adsorption precipitation reaction in the rhizosphere, and then inhibited the phosphorus into plant roots and transportation aboveground (Cumming \& Ning, 2003; Macklon, Lumsdon, \& Sim, 1994). Al ${ }^{3+}$ also could be combined with the phosphate-based DNA, inhibiting DNA replication and biosynthesis, thereby affecting the cells mitosis, and consequently reducing plant performance (Clarkson, 1985). For legume crops, higher concentrations of $\mathrm{Al}^{3+}$ in acidic soil also inhibited the growth of rhizobia, reduced the affinity between rhizobia and root system, and limited the biological nitrogen fixation (Whelan \& Alexander, 1986).

In order to alleviate the aluminum toxicity and to improve crop yield in acid soils, alkaline ameliorators, such as lime, have been applied to neutralize acidity and increase nutrient availabilities (Crusciol et al., 2016). Lime application will increase soil $\mathrm{pH}$ and concentrations of $\mathrm{Ca}^{2+}$ and $\mathrm{Mg}^{2+}$, decrease concentrations of $\mathrm{Al}^{3+}$ and $\mathrm{Mn}^{2+}$ ions, and thus improve the soil phosphorus nutrition and crop yield (Cai, Xiao, \& Li, 2010). Lime application improved the soil microbial carbon, nitrogen, respiration rate and metabolic quotient $\left(\mathrm{qCO}_{2}\right)(\mathrm{M}$. Stenberg, B. Stenberg, \& Rydberg, 2000), increased the number and diversity of rhizobia (Denton, Coventry, Bellotti, \& Howieson, 2000) and the activity of antioxidant enzymes (POD, SOD and CAT) in plants (Xiao, Yang, Xiao, \& Xie, 2003). However, surface lime application mainly affected the soil layer to depths of only $5 \mathrm{~cm}$, and inappropriate lime application rates or timing might cause imbalances of soil $\mathrm{Ca}^{2+}, \mathrm{K}^{+}$and $\mathrm{Mg}^{2+}$, resulting in low yields (Walker, 2002). Further, the efficiency of lime application was also associated with other factors such as rainfall distribution, soil texture, structure, hydraulic conductivity, fauna, and crop rotation and management (Edmeades \& Ridley, 2003).

Besides lime application, selecting Al tolerant crop genotypes is the most fundamental method in relieving the negative effects of acid soil on plants (Choudhary, Singh, \& Iquebal, 2011). Tolerance to Al was observed in some plant species and varied among genotypes (Castilhos et al., 2011; Choudhary et al., 2011; Jan, 1991). On molecular level, genes controlling $\mathrm{Al}^{3+}$ resistance had also been cloned from wheat (Triticum aestivum L.), barley (Hordeum vulgare L.), rye (Secale cereale L.), sorghum (Sorghum bicolour (L.) Moench) and rice (Oryza sativa L.) (Ryan \& Delhaize, 2010). However, the long and complex process of breeding Al resistant variety makes this still impractical today (Nawrot et al., 2001; Seguel et al., 2013). For alfalfa, no Al tolerant cultivars has been reported though many studies were conducted in screening Al tolerance in alfalfa cultivars (Langer et al., 2009; Khu, Reyno, Brummer, \& Monteros, 2012; Pan, Zhu, \& Cheng, 2008).

Legume crops form two types of symbiosis, nodule (with rhizobium) and mycorrhizae (with arbuscular mycorrhizal fungus, AMF). Though the rhizobia have been shown to be sensitive to $\mathrm{Al}^{3+}$, AMF are widely distributed in acid soils and show relative tolerance to $\mathrm{Al}^{3+}$ (Clark, 1997; Guo et al., 2012; Fritz et al., 2010). The formation of mycorrhizae could regulate the relationship between soil aluminum, phosphorus and plant, protecting roots from the Al toxicity (Vandamme et al., 2013). AMF could improve the growth of plant in acid soils, enhance the acid resistance (Heijne, Dam, Heil, \& Bobbink, 1996), and strengthen the resistance of plants to $\mathrm{Al}^{3+}$ (Thompson \& Medve, 1984). In a pot experiment, AMF inoculation increased nodule numbers, total nodule weight, and yields of alfalfa in an acid soil with pH of 5.45 (Guo, Ni, \& Huang, 2010). However, mycorrhizal fungi differ in their responses to soil pH (Cavallazzi, Filho, Stürmer, Rygiewicz, \& Mendonça, 2007), and in their colonization with plant species (Orłowska, Ryszka, Jurkiewicz, \& Turnau, 2005). Therefore, selecting effective AMF strains might be an alternative choice in improving alfalfa production in acid soils.

M. lupulina (black medick), belonging to the same genus with alfalfa, is widely distributed in temperate and subtropical regions and possesses the tenacious survival and reproduction ability (Yan, Chu, Wang, Li, \& Tao, 2009). Yurkova, Jacobi, Gapeeva, Stepanova, and Shishova (2015) reported that the black medick cultivar-population could be characterized as an ecologically obligate mycotrophic plant under conditions of low level of available phosphorus in the soil. A long-term cover cropping with black medic showed that Triticum aestivum following black medic had a higher early percent root length colonized by AMF, suggesting that cover cropping with black medic was an effective method of increasing early AMF colonization (Turmel, 2007). These results suggested that AMF from black medick might be effective in low fertility soils, benefiting its wide distribution. Therefore, in the current study, we collected AMF spores from rhizosphere soils growing black medick and identified AMF strains using molecular method (Guo et al., 2012). The AMF spores were inoculated solely or dual inoculated with rhizobia in soils with three $\mathrm{Al}^{3+}$ levels growing black medick or alfalfa. We measured plant aboveground and underground biomass, branching number, root length, area and volume, plant nutrients, soil nutrients, AMF colonization, and nodulation, aiming to confirm whether these AMF could improve alfalfa growth and quality in acid soils. 


\section{Materials and Methods}

\subsection{Soils}

The soil was a sandy yellow soil (Orthic Acrisols) with a $\mathrm{pH}$ of 5.34, collected from crop lands in Jigong Mountain, Beibei $\left(29^{\circ} 49^{\prime} \mathrm{N}, 106^{\circ} 25^{\prime} \mathrm{E}\right)$, Chongqing, China. The crop lands were cropped with maize and sweet potato for at least 10 years, and no plant from Megicago genus was planted. The soils were collected from 0-20 $\mathrm{cm}$ layer, air dried, stones and plant debris removed, sieved through $2 \mathrm{~mm}$ mesh, and wet sterilized at $121{ }^{\circ} \mathrm{C}$ for $25 \mathrm{~min}$. The soil organic carbon, total nitrogen $(\mathrm{N})$, phosphorus $(\mathrm{P})$ and potassium $(\mathrm{K})$ were $22.83,0.79,0.56$ and $18.33 \mathrm{~g} / \mathrm{kg}$, respectively. The concentrations of available N, P and $\mathrm{K}$ were $100.12,20.16$ and $112.5 \mathrm{mg} / \mathrm{kg}$, respectively. The CEC of the soil was $8.54 \mathrm{cmol}(+) / \mathrm{kg}$, with the concentration of $\mathrm{Al}^{3+}$ reaching $1100 \mathrm{mg} / \mathrm{kg}$.

\subsection{Plant Materials}

The alfalfa cultivar, Medicago sativa cv Sanditi, was bred in France by the Royal Barenbrug Group (The Netherlands), imported to China by Barenbrug China (Beijing), and has been widely grown in subtropical areas of China with a dormancy of 5.2 (Shen et al., 2013). The seeds of black medick (Medicago lupulina) were directly collected from uncultivated fields located in Beibei, Chongqing. The seeds were washed clean of commercial coating (for Sanditi) and placed on wet paper in Petri dishes under dark conditions for $12 \mathrm{~h}$ prior to sowing.

\subsection{Symbiotic Microbes}

The tested rhizobia were separated from root nodules of $M$. lupulina in field and $M$. sativa which has been cultivated for four years. They were purified and propagated using YMA medium (yeast morphology agar). The inoculants were propagated using YMA medium without agar.

The tested AMF spores were directly collected from the rhizosphere soils of wild black medick, using the wet sieving and decanting methods described by Zhao et al. (2001). In total ca. $50 \mathrm{~kg}$ soils from ca. 200 plants were wet sieved and ca. $300 \mathrm{~g}$ spores and sporocarps were obtained. Since the spores isolated from soils were a mixture, the DNA of the soils was extracted and used for AMF identification followed by the method of Guo et al. (2012). In total 5 strains were identified, mainly Glomus species (Table 1). The isolated spores and sporocarps were mixed with autoclaved sand (2:1), reaching a spore density of $150 / \mathrm{g}$ inoculants. The mixture was directly used as inoculants.

\subsection{Experiment Design}

A two-way completely randomized factorial design was employed for each plant species with two inoculations (rhizobia and $\mathrm{AMF}$ ) and three $\mathrm{Al}^{3+}$ levels, and replicated four times. The soil $\mathrm{Al}^{3+}$ levels were adjusted to 900 $\mathrm{mg} / \mathrm{kg}$ (Al1), $1000 \mathrm{mg} / \mathrm{kg}(\mathrm{Al} 2)$ and $1100 \mathrm{mg} / \mathrm{kg}(\mathrm{Al} 3)$, by adding lime $\left(\mathrm{Ca}(\mathrm{OH})_{2}\right)$ equivalent to $1.5 \mathrm{~g} / \mathrm{kg}, 0.75$ $\mathrm{g} / \mathrm{kg}$ and $0 \mathrm{~g} / \mathrm{kg}$, respectively. About $1.5 \mathrm{~kg}$ dry soils were put into one pot $(18 \mathrm{~cm}$ diameter, $14 \mathrm{~cm} \mathrm{height)} \mathrm{and}$ saturated with water for 15 days before sowing.

For AMF treatment, about $5 \mathrm{~g}$ inoculants were applied at a depth of $8 \mathrm{~cm}$ of the pot before sowing. Non-AMF treatments received same amount of autoclaved sand. The rhizobia inoculant was applied 3 times, one at the day of transplanting, and the other two at next two weeks. At each application time, each pot received ca. $5 \times 10^{4}$ bacteria based on an assessment of the numbers of Rhizobia present in a bacterial culture by carrying out serial dilution. The application was done with watering. Non-rhizobia treatments received the same amount of autoclaved medium. Each plant species contained non-inoculated group, AMF group, Rhizobia group, and $\mathrm{AMF}+$ Rhizobia group, grown in soils with three different $\mathrm{Al}^{3+}$ levels.

Ten seedlings were transplanted in each pot and thinned to six plants per pot one week later. The pots were watered twice a week, keeping the relative soil moisture content between $50 \%-75 \%$. The pots were placed in a glasshouse accepting sunlight, with temperatures ranging from $20{ }^{\circ} \mathrm{C}$ to $25{ }^{\circ} \mathrm{C}$ during daytime and $15{ }^{\circ} \mathrm{C}$ to $20{ }^{\circ} \mathrm{C}$ during night. The pot positions were adjusted once every week. 
Table 1. AMF strains isolated from soils of Medicago lupulina

\begin{tabular}{llllll}
\hline Clone No. & Accession No. & $\begin{array}{l}\text { The strains which have the } \\
\text { highest identity from NCBI }\end{array}$ & Accession No. & Similarity & Query coverage \% \\
\hline 1 & KY235383 & Glomus mosseae & GU966531.1 & $99 \%$ & $99 \%$ \\
2 & KY235384 & Uncultured Glomus & FR871390.1 & $99 \%$ & $96 \%$ \\
3 & KY235385 & Glomus $s p$ & FM876806.1 & $99 \%$ & $100 \%$ \\
4 & KY235386 & Uncultured Glomus & JQ218217.1 & $96 \%$ & $100 \%$ \\
5 & KY235387 & Glomus $s p$ & FM876804.1 & $97 \%$ & $100 \%$ \\
\hline
\end{tabular}

\subsection{Measurements}

\subsubsection{Plant Growth Measurement}

After two and a half months of growth, the plants were harvested and separated into shoots and roots, and the height and branching number were measured. The shoots were dried at $105^{\circ} \mathrm{C}$ for 20 min and then at $75^{\circ} \mathrm{C}$ for $48 \mathrm{~h}$, and then weighed. The roots were carefully washed with distilled water in sieve, nodule number, root length, surface area and volume were recorded using a root scanner (WinRHIZO). Part of roots (ca. $0.2 \mathrm{~g}$ ) was used for measuring AMF colonization, with the remaining roots dried at $75^{\circ} \mathrm{C}$ for $48 \mathrm{~h}$ and weighed.

\subsubsection{Plant Nutrient Analysis}

Dried shoots were ground, sieved through $0.5 \mathrm{~mm}$ mesh, and digested in $\mathrm{HNO}_{3} / \mathrm{H}_{2} \mathrm{O}_{2}$ solution. The digested solution was used to analyze total nitrogen (TN), total phosphorus (TP) and total potassium (TK). TN was measured by the Kjeldhal method, TP was determined by vanadomolybdophosphoric yellow color method, TK was measured by flame atomic absorption spectrometric method (Bao, 2005).

\subsubsection{Soil $\mathrm{pH}$ and Concentrations of Aluminum, Available Nitrogen, Phosphorus and Potassium}

Soil $\mathrm{pH}$ value was determined in a soil: water (1:5) solution using a $\mathrm{pH}$ meter. Aluminum concentration was determined by eriochrome cyanine R spectrophotometric method (Qiu, 1989). Alkali dispelled nitrogen (AN) was determined by titration method. Extraction of available $\mathrm{P}$ were carried out using $\mathrm{HCl}-\mathrm{NH}_{4} \mathrm{~F}$, and analyzed using the ammonium molybdate method (Olsen \& Sommers, 1982). Available K were extracted by $\mathrm{NH}_{4} \mathrm{OAc}$ and analyzed by flame atomic absorption spectrometric method.

\subsubsection{AMF Colonization}

Approximately $0.5 \mathrm{~g}$ of roots were cleared in $2 \% \mathrm{KOH}(\mathrm{w} / \mathrm{v})$ at $90{ }^{\circ} \mathrm{C}$ for $60 \mathrm{~min}$ and rinsed three times in water. The root samples were acidified in $2 \% \mathrm{HCl}(\mathrm{v} / \mathrm{v})$ for $30 \mathrm{~min}$ and then stained in $0.05 \%(\mathrm{w} / \mathrm{v})$ trypan blue in lactoglycerol for $30 \mathrm{~min}$ at $90^{\circ} \mathrm{C}$. Root segments of each plant species were selected randomly and assessed for the presence or absence of AMF structures (arbuscules, vesicles and thick hyphae) using a stereomicroscope. AMF colonization were distinguished from non-mycorrhizal fungi as described by Callaway, Mahall, Wicks, Pankey, and Zabinski (2003). Colonization was expressed as frequency of mycorrhiza in the root system (F\%) and intensity of the mycorrhizal colonization in the root system (M\%) according to the method of Trouvelot, Kough, and Gianinazzi-Pearson (1986). In total three slides with 45 root segments in each root sample were observed under the microscope and rated according to the range of classes based on Mycorrhizal Manual (http://www2.dijon.inra.fr/mychintec/Protocole/protoframe.html). The values were put into the computer program 'Mycocalc' to calculate F, M and A.

\subsection{Data Analyses}

The data were the average from four replicates. Two-way ANOVA analysis was applied to analyze the effects of $\mathrm{Al}^{3+}$ concentrations and inoculation and their interactions on plant and soil parameters (SPSS 17.0, USA). Due to the significant interactions between $\mathrm{Al}^{3+}$ and inoculation, the effects of inoculation on soil and plant parameters were further analyzed using one-way ANOVA analysis at each $\mathrm{Al}^{3+}$ level, separately. The significance was based on the least significant difference test at $\mathrm{P}<0.05$. Pearson's correlation analysis was conducted to examine the relationship between soil parameters and plant parameters.

\section{Results}

The two-way ANOVA analysis indicated that soil $\mathrm{Al}^{3+}$ levels significantly influenced all parameters from both plants and soils, whereas inoculations significantly influenced shoot weight, root/shoot ratio, phosphorus concentration in plant, root length, surface area and volume from both plant species, and all soil parameters 
except soil $\mathrm{pH}$ for M. lupulina (Table 2). There existed significant interactions between $\mathrm{Al}^{3+}$ levels and inoculations, varying between the two plant species.

Table 2. Analysis of variance of main effects $\left(\mathrm{Al}^{3+}\right.$ concentration and inoculation) and their interactions for plant growth parameter and soil nutrients

\begin{tabular}{|c|c|c|c|c|c|c|}
\hline & \multicolumn{3}{|c|}{ Medicago sativa } & \multicolumn{3}{|c|}{ Medicago lupulina } \\
\hline & $\mathrm{Al}$ & Inoculation (I) & $\mathrm{Al} \times \mathrm{I}$ & $\mathrm{Al}$ & Inoculation (I) & $\mathrm{Al} \times \mathrm{I}$ \\
\hline Height & $129.06^{* * *}$ & $3.44 * *$ & $0.22 \mathrm{~ns}$ & $199.10^{* * *}$ & $2.09 \mathrm{~ns}$ & $1.09 \mathrm{~ns}$ \\
\hline Branching number & $57.98 * * *$ & $4.10^{* *}$ & $1.83 \mathrm{~ns}$ & $608.45^{* * *}$ & $1.40 \mathrm{~ns}$ & $6.10^{* * *}$ \\
\hline Shoot weight & $150.20 * * *$ & $6.11 * * *$ & $0.49 \mathrm{~ns}$ & $1438.49 * * *$ & $10.79 * * *$ & $9.58 * * *$ \\
\hline Root weight & $106.35^{* * *}$ & $9.93^{* * *}$ & $2.51^{* *}$ & $86.74 * * *$ & $1.80 \mathrm{~ns}$ & $0.53 \mathrm{~ns}$ \\
\hline Root/Shoot ratio & $21.30 * * *$ & $2.28 *$ & $3.41 * *$ & $67.22 * * *$ & $5.52 * * *$ & $3.72 * * *$ \\
\hline Nitrogen content in plant & $75.74 * * *$ & $6.21 * * *$ & $5.02 * * *$ & $192.13^{* * *}$ & $1.62 \mathrm{~ns}$ & $4.16^{* * *}$ \\
\hline Phosphorus content in plant & $7.01 * * *$ & $13.10 * * *$ & $5.62 * * *$ & $7.14 * * *$ & $10.32 * * *$ & $2.51 * *$ \\
\hline Potassium content in plant & $12.76^{* * *}$ & $1.12 \mathrm{~ns}$ & $0.92 \mathrm{~ns}$ & $33.69^{* * *}$ & $2.21 \mathrm{~ns}$ & $4.25^{* * *}$ \\
\hline Root length & $600.13 * * *$ & $9.78 * * *$ & $6.37 * * *$ & $1326.30^{* * *}$ & $14.46^{* * *}$ & $10.30^{* * *}$ \\
\hline Root surface area & $789.25^{* * *}$ & $4.74 * * *$ & $31.01 * * *$ & $1383.70^{* * *}$ & $19.90 * * *$ & $13.13 * * *$ \\
\hline Root volume & $364.61 * * *$ & $9.31 * * *$ & $23.85^{* * *}$ & $543.08 * * *$ & $12.76^{* * *}$ & $13.90 * * *$ \\
\hline Soil available nitrogen concentration & $73.33 * * *$ & $3.43 * *$ & $2.37 *$ & $13.87 * * *$ & $6.73 * * *$ & $1.58 \mathrm{~ns}$ \\
\hline Soil available phosphorus concentration & $623.77 * * *$ & $6.39 * * *$ & $1.76 \mathrm{~ns}$ & $1453.17 * * *$ & $3.16^{* *}$ & $1.51 \mathrm{~ns}$ \\
\hline Soil available potassium concentration & $230.47^{* * *}$ & $19.12 * * *$ & $3.95 * * *$ & $285.72 * * *$ & $5.48 * * *$ & $5.65^{* * *}$ \\
\hline Soil $\mathrm{pH}$ & $309.3 * * *$ & $2.74 *$ & $2.46^{* *}$ & $428.49^{* * *}$ & $1.21 \mathrm{~ns}$ & $0.95 \mathrm{~ns}$ \\
\hline Soil available aluminum concentration & $373.00 * * *$ & $8.68 * * *$ & $14.18 * * *$ & $708.68 * * *$ & $4.01 * *$ & $1.67 \mathrm{~ns}$ \\
\hline
\end{tabular}

Note. “***”represent significant at $\mathrm{P}<0.001$; “**”represent significant at $\mathrm{P}<0.01$; “*”represent significant at $\mathrm{P}$ $<0.05$.

\subsection{Plant Height and Branching Number}

Overall, the plant height and branching number from both plant species decreased with increased soil $\mathrm{Al}^{3+}$ concentrations (Figure 1). Compared to plant height at Al1, alfalfa height reduced by $25.70 \%$ at $\mathrm{Al} 2$ and $68.60 \%$ at $\mathrm{Al} 3$ (Figure 1A), while black medick height reduced by $27.06 \%$ at $\mathrm{Al} 2$ and $74.62 \%$ at $\mathrm{Al} 3$ (Figure 1C). The average branching number of alfalfa reduced from 14.44 per pot at All to 11.56 at Al2 and to 6.56 at Al3 (Figure 1B), whereas that in black medick reduced from 24.81 at Al1 to 20.5 at Al2 and to 7.0 at Al3 (Figure 1D).

AMF inoculation (solely or dual) exhibited a trend in increasing plant height and branching number of alfalfa at all three $\mathrm{Al}^{3+}$ levels, but no significant difference could be observed except for a significant increase in branching number at Al2. For black medick, only dual inoculation at Al3 significantly increased both height and branching number, with no significant changes of plant height at All and Al2, and a decrease of branching number at All and $\mathrm{A} 12$ for dual inoculation. 

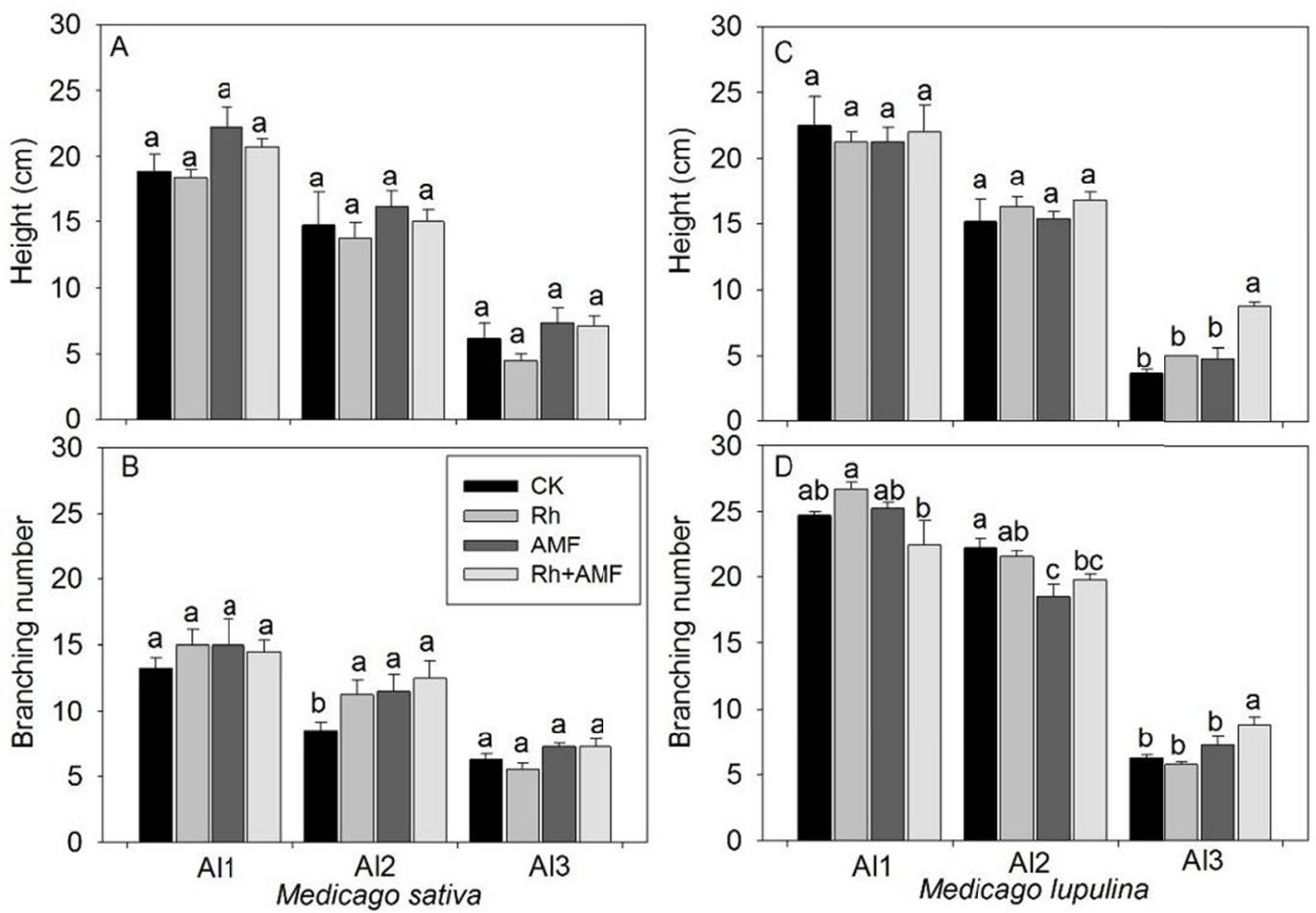

Figure 1. Effects of inoculation on height and branching number of Medicago sativa and M. lupulina grown in acid soils with different $\mathrm{Al}^{3+}$ concentrations

Note. Different small letters above the data bar represented significance at $\mathrm{P}<0.05$ (LSD). CK, Rh, AMF and $\mathrm{Rh}+\mathrm{AMF}$ represented non-inoculation, rhizobia inoculation, AMF inoculation and co-inoculation with rhizobia and AMF, respectively.

\subsection{Shoot Weight, Root Weight and Root to Shoot Ratio}

Shoot and root weight decreased with increased $\mathrm{Al}^{3+}$ concentrations for both plant species (Figure 2). For example, the shoot weight at All was 1.32 and 6.23 times of those at Al2 and Al3 for alfalfa (Figure 2A), and 1.54 and 9.08 times for black medick, respectively (Figure 2D). The root weight at Al1 was 1.47 and 12.03 times for alfalfa and 1.68 and 5.17 times for black medick at Al2 and Al3, respectively (Figures 2B and 2E). Due to the inconsistent responses of shoot and root weight to changes of $\mathrm{Al}^{3+}$ concentration, the root to shoot ratio decreased by $43.38 \%$ for alfalfa from $\mathrm{All}$ to $\mathrm{Al} 3$, whereas increased by $86.67 \%$ for black medick from Al1 to Al3 (Figures 2C and 2F).

The responses of shoot and root weight to inoculations differed between the two plant species. For alfalfa, AMF inoculation and dual inoculation increased shoot and root weight at all $\mathrm{Al}^{3+}$ concentrations except for insignificant changes of shoot weight at All and Al2 for dual inoculation and root weight at Al3 for AMF inoculation. For black medick, inoculation also had a trend in increasing shoot and root weight at All and Al2. At Al3, only dual inoculation significantly increased shoot and root weight of black medick. The root to shoot ratio of alfalfa inoculated with AMF was significantly higher than those inoculated with rhizobia solely at Al1 and $\mathrm{Al} 2$ but not at $\mathrm{Al}$. For black medick, root to shoot ratio at all $\mathrm{Al}^{3+}$ concentrations remained unchanged except for a decrease at $\mathrm{Al} 3$ for dual inoculation. 

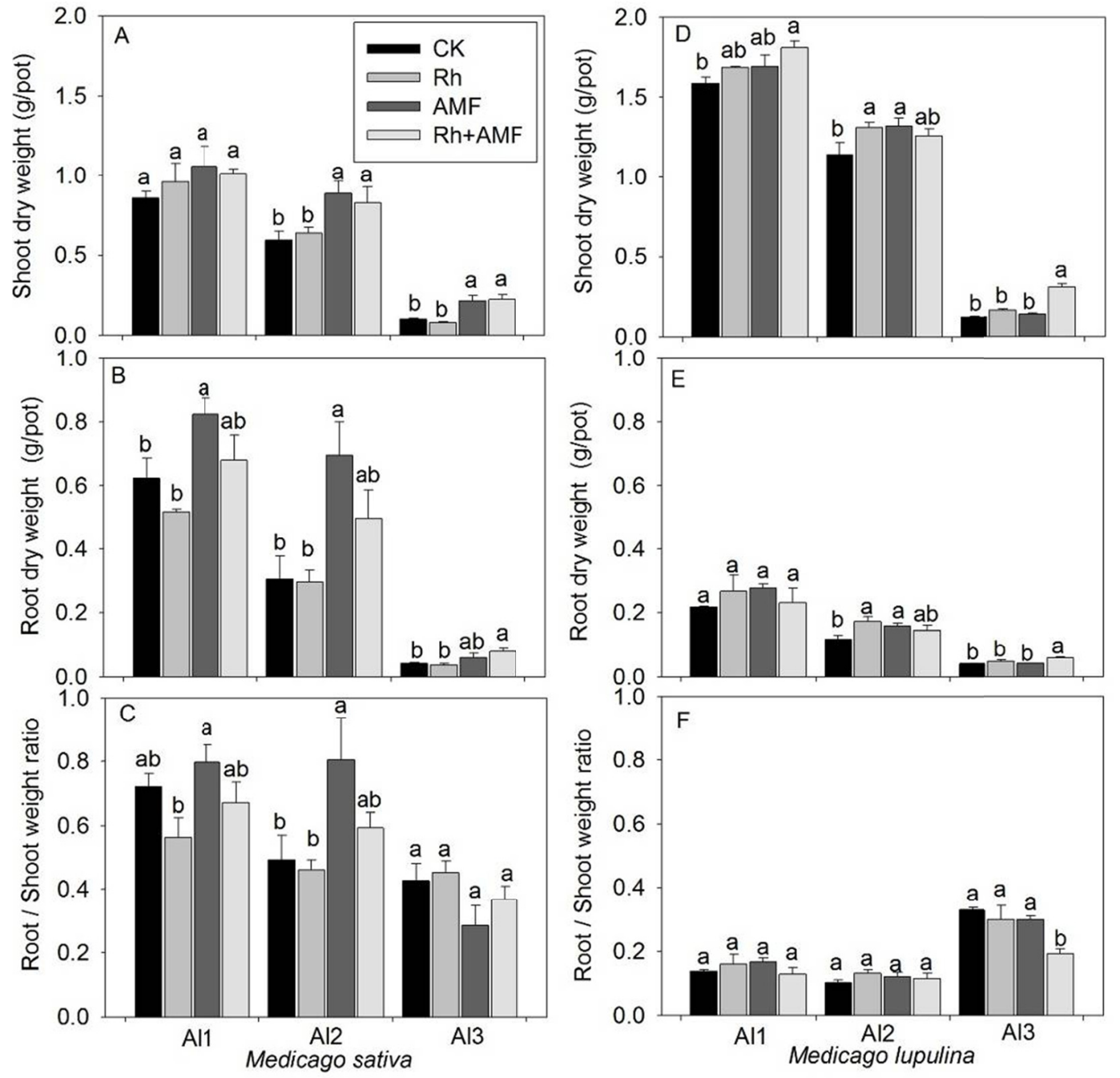

Figure 2. Effects of inoculation on shoot and root weight of Medicago sativa and M. lupulina grown in acid soils with different $\mathrm{Al}^{3+}$ concentrations

Note. Different small letters above the data bar represented significance at $\mathrm{P}<0.05$ (LSD). CK, Rh, AMF and $\mathrm{Rh}+\mathrm{AMF}$ represented non-inoculation, rhizobia inoculation, AMF inoculation and co-inoculation with rhizobia and AMF, respectively.

\subsection{Root Length, Root Area and Root Volume}

The root length, root area and root volume of both plant species reduced with increased Al concentrations except for root length and root area of alfalfa at Al2 (Figure 3). Great decrease was observed from Al2 to Al3 for both plant species. For example, root length, root area and root volume reduced by $74.96 \%$ and $70.98 \%, 68.05 \%$ and $63.06 \%$, and $60.34 \%$ and $53.59 \%$ for alfalfa and black medick, respectively, when $\mathrm{Al}^{3+}$ concentration increased from $\mathrm{A} 12$ to $\mathrm{Al} 3$.

Overall, AMF inoculation had a trend in increasing root length, root area and root volume for both plant species at $\mathrm{Al} 2$ and $\mathrm{Al}$. At Al1, root length was unchanged whereas root area and root volume significantly reduced due to inoculation for alfalfa (Figures 3A, 3B and 3C). For black medick at Al1, root length, root area and root volume of dual inoculated plants was significantly higher than those of other treatments except for root length inoculated with rhizobia solely (Figure 3D). 

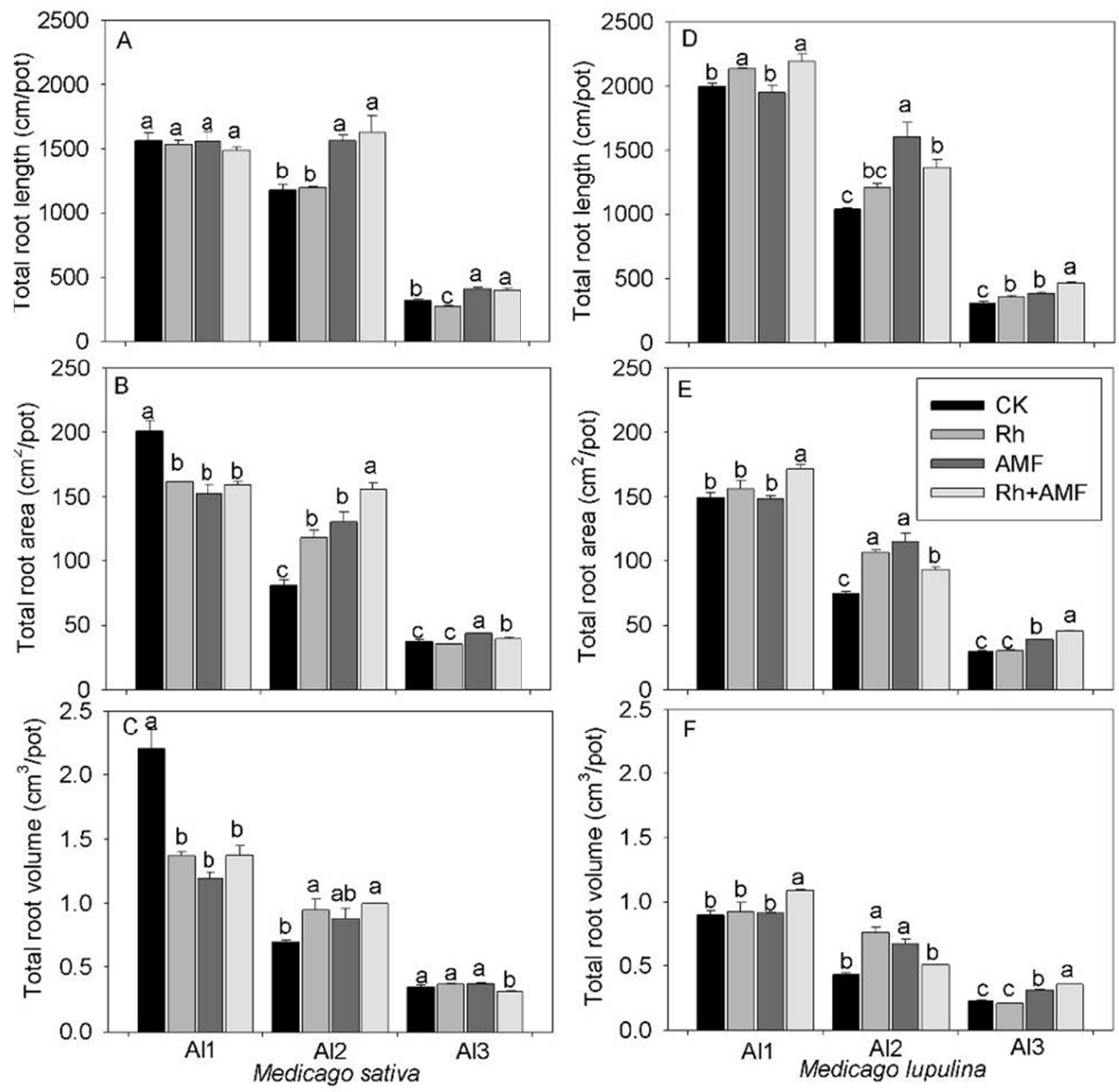

Figure 3. Effects of inoculation on root length (A, D), surface area (B, E) and volume (C, F) of Medicago sativa and M. lupulina grown in acid soils with different $\mathrm{Al}^{3+}$ concentrations

Note. Different small letters above the data bar represented significance at $\mathrm{P}<0.05$ (LSD). CK, Rh, AMF and $\mathrm{Rh}+\mathrm{AMF}$ represented non-inoculation, rhizobia inoculation, AMF inoculation and co-inoculation with rhizobia and AMF, respectively.

\subsection{Contents of Plant Nitrogen, Phosphorus and Potassium}

Overall, concentrations of nitrogen, phosphorus and potassium in both plant species increased with increased $\mathrm{Al}^{3+}$ concentrations except for a decrease of phosphorus (3.33\%) and potassium (9.25\%) in black medick at $\mathrm{Al} 3$ (Figure 4). The increase rate (compared to Al1) of phosphorus and potassium contents ranged from $6.14 \%$ to $9.80 \%$ and $7.82 \%$ to $13.67 \%$, respectively. Increase rate less than $10 \%$ was also observed for nitrogen content when soil $\mathrm{Al}$ increased from $\mathrm{All}$ to $\mathrm{Al} 2$, whereas they increased to $36.54 \%$ in alfalfa and $43.28 \%$ in black medick when soil Al increased from All to Al3.

The effects of inoculation on plant nutrients differed between plant species and among $\mathrm{Al}^{3+}$ concentrations. For alfalfa, contents of nitrogen and potassium unchanged after inoculation at all $\mathrm{Al}^{3+}$ concentrations except a decrease of nitrogen content after AMF and rhizobia inoculation solely at Al2. Phosphorus contents increased for AMF and dual inoculation at Al1 and AMF inoculation at Al3 (Figure 4B). The contents of phosphorus in plants inoculated with rhizobia was significantly lower than those inoculated with AMF and both AMF and rhizobia at Al1, those inoculated with both AMF and rhizobia at Al2, and those inoculated with AMF at Al3. For black medick, the contents of nitrogen increased after inoculation at $\mathrm{Al} 2$ and unchanged at the other two $\mathrm{Al}^{3+}$ 
concentrations, the contents of phosphorus increased after inoculation at $\mathrm{Al} 3$ and unchanged at the other two $\mathrm{Al}^{3+}$ concentrations, whereas the contents of potassium unchanged at all $\mathrm{Al}^{3+}$ concentrations except for a lower potassium content for AMF and dual inoculation than rhizobia at A12 (Figure 4F).
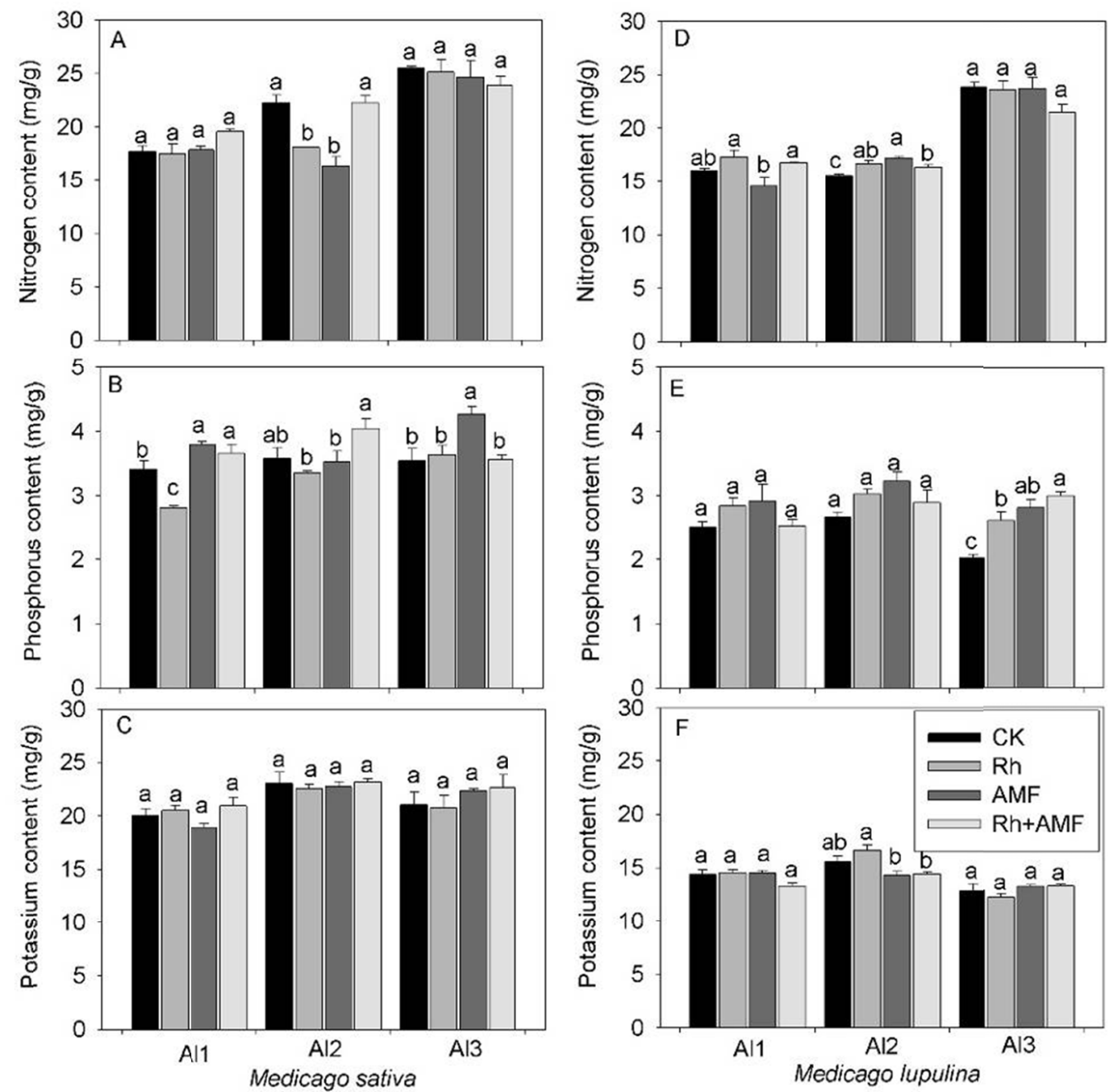

Figure 4. Effects of inoculation on contents of nitrogen (A, D), phosphorus (B, E) and potassium (C, F) in Medicago sativa and M. lupulina grown in acid soils with different $\mathrm{Al}^{3+}$ concentrations

Note. Different small letters above the data bar represented significance at $\mathrm{P}<0.05$ (LSD). CK, Rh, AMF and $\mathrm{Rh}+\mathrm{AMF}$ represented non-inoculation, rhizobia inoculation, AMF inoculation and co-inoculation with rhizobia and AMF, respectively.

\subsection{Soil pH and Concentrations of Aluminum, Available Nitrogen, Phosphorus and Potassium}

Soils were collected after plants were harvested and analyzed for $\mathrm{pH}$, concentrations of aluminum, available nitrogen, phosphorus and potassium. Compared to the initial ones before planting, soil $\mathrm{pH}$ changed insignificantly, whereas concentrations of $\mathrm{Al}^{3+}$, available nitrogen, available phosphorus and available potassium all decreased at All (Figures 5 and 6). With increased $\mathrm{Al}^{3+}$ levels, soil $\mathrm{pH}$ reduced, whereas concentrations of available nitrogen, phosphorus and potassium increased except for concentrations of available nitrogen at $\mathrm{Al} 2$ which unchanged from A12 to Al3 for alfalfa (Figure 6A) and reduced from Al1 to Al2 for black medick (Figure $6 \mathrm{D})$.

The effects of inoculation on soil parameters varied greatly among $\mathrm{Al}^{3+}$ concentrations and plant species. Soil $\mathrm{pH}$ unchanged for both plant species except for an increase in all inoculations for alfalfa at A12 and a decrease in 
dual inoculation at $\mathrm{Al} 3$ for alfalfa (Figure 5A). The concentrations of $\mathrm{Al}^{3+}$ decreased for alfalfa after inoculation at Al1, whereas increased when inoculated with AMF and dual inoculation at Al2 and Al3 (Figure 5B). For black medick, no significant changes were observed after inoculation at All and Al3, whereas AMF and dual inoculation increased concentrations of $\mathrm{Al}^{3+}$ at $\mathrm{Al} 2$ (Figure 5D). Compared to the un-inoculated ones, inoculation with rhizobia increased the concentrations of available nitrogen at Al1, available phosphorus at Al2, and available potassium at all $\mathrm{Al}^{3+}$ levels for alfalfa, whereas $\mathrm{AMF}$ inoculation increased the concentrations of phosphorus at Al1 and Al2 and potassium at All for alfalfa. For black medick, inoculation had no significant influence on the concentrations of available nitrogen, phosphorus and potassium except for a significant increase of available nitrogen for dual inoculation at All (Figure 6D), and an increase of available potassium for dual inoculation at All and AMF solely and dual inoculation at Al2 (Figure 6F).
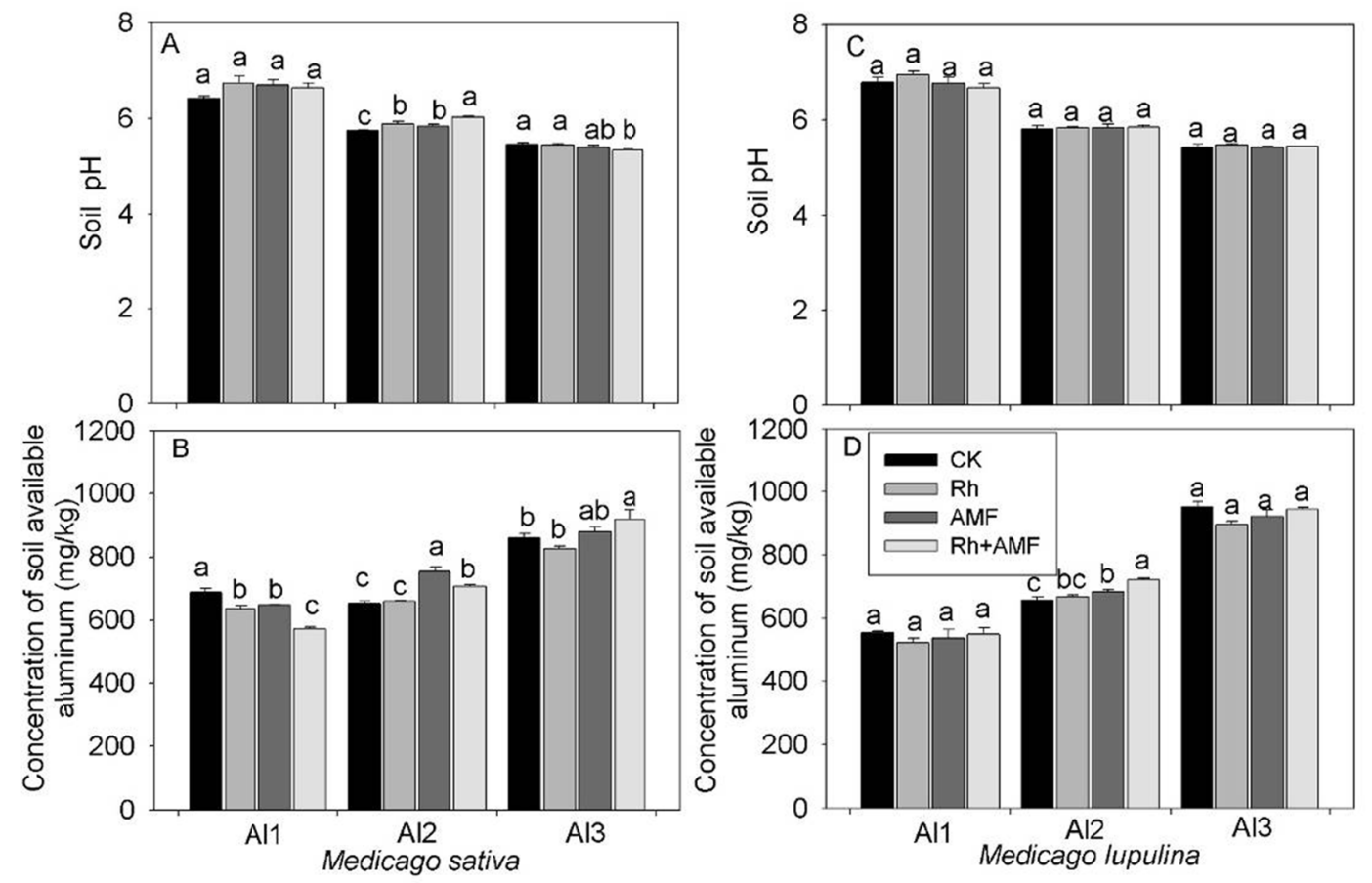

Figure 5. Effects of inoculation on soil $\mathrm{pH}(\mathrm{A}, \mathrm{C})$ and concentrations of soil available aluminum (B, D) in Medicago sativa and M. lupulina grown in acid soils with different $\mathrm{Al}^{3+}$ concentrations

Note. Different small letters above the data bar represented significance at $\mathrm{P}<0.05$ (LSD). CK, Rh, AMF and $\mathrm{Rh}+\mathrm{AMF}$ represented non-inoculation, rhizobia inoculation, AMF inoculation and co-inoculation with rhizobia and $\mathrm{AMF}$, respectively. 

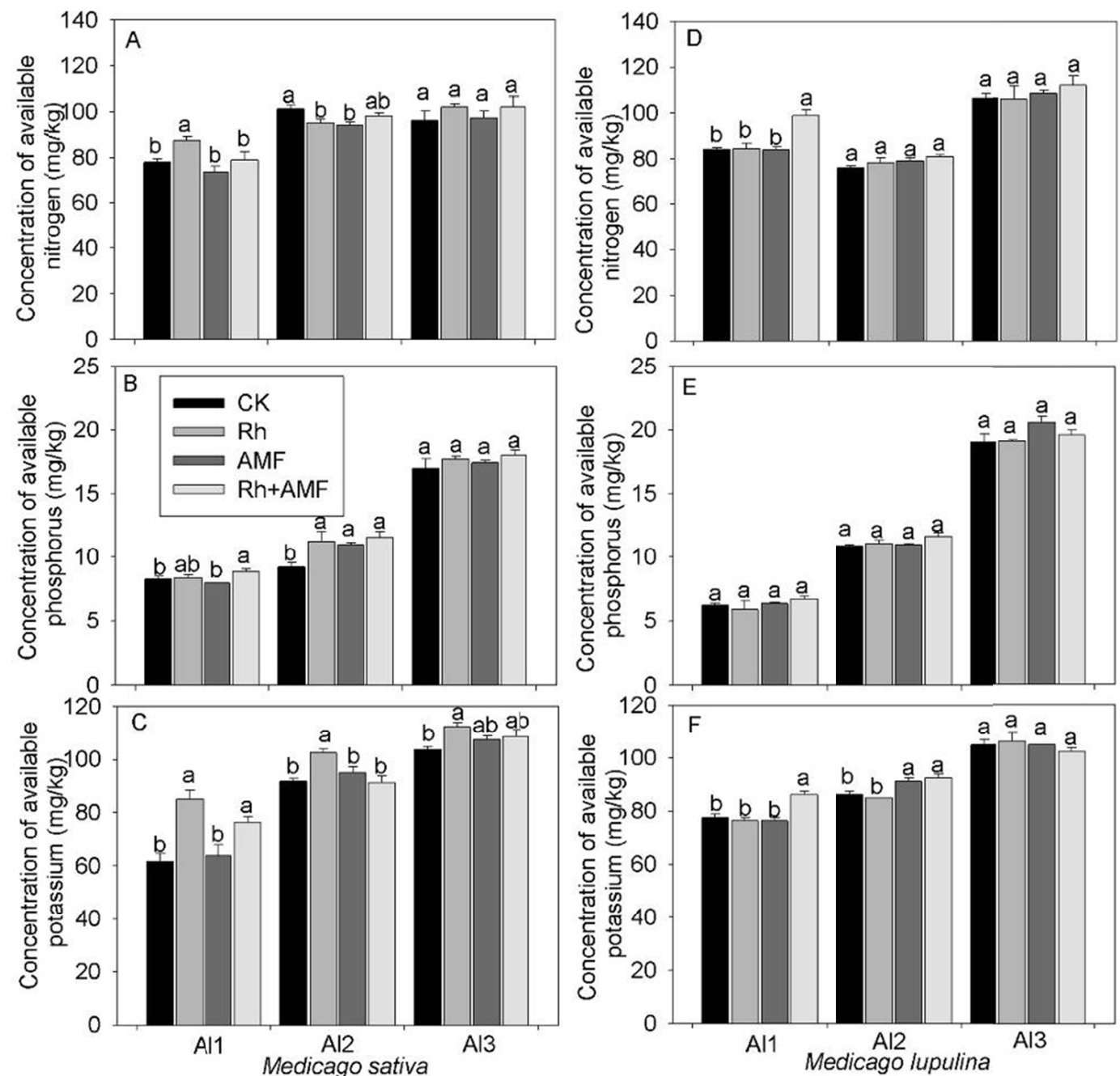

Figure 6. Effects of inoculation on concentrations of soil available nitrogen (A, D), available phosphorus (B, E) and available potassium (C, F) in Medicago sativa and M. lupulina grown in acid soils with different $\mathrm{Al}^{3+}$ concentrations

Note. Different small letters above the data bar represented significance at $\mathrm{P}<0.05$ (LSD). CK, Rh, AMF and $\mathrm{Rh}+\mathrm{AMF}$ represented non-inoculation, rhizobia inoculation, AMF inoculation and co-inoculation with rhizobia and AMF, respectively.

\subsection{AMF Colonization and Nodulation}

$\mathrm{Al}$ concentrations and inoculation significantly influenced nodulations and AMF colonization except for $\mathrm{F} \%$ in both plant species and $\mathrm{M} \%$ in black medick, and there existed significant interactions between $\mathrm{Al}^{3+}$ concentration and inoculation for all parameters (Table 3). Dual inoculation significantly increased nodule number at All and A12 in both plant species. No nodule was observed at Al3. The influence of dual inoculation on AMF colonization differed among soil $\mathrm{Al}^{3+}$ concentrations and between plant species. For alfalfa, $\mathrm{F} \%$ and $\mathrm{M} \%$ increased after dual inoculation at Al1, whereas decreased at A12 and Al3 except for an insignificant increase of $\mathrm{F} \%$ at $\mathrm{Al} 3$. For black medick, dual inoculation had no significant influence on colonization except for a significant increase of $\mathrm{M} \%$ at $\mathrm{Al} 2$ and decrease at $\mathrm{Al} 3$.

\subsection{Correlation Analysis}

Correlation analysis indicated that shoot and root weight were positively correlated with root length, surface area and volume, plant height, and branching number, whereas negatively correlated with contents of plant nitrogen, phosphorus and potassium except for positive relationship between root weight and phosphorus and potassium 
contents (Table 4). Among the contents of plant nitrogen, phosphorus and potassium, only the nitrogen content was positively correlated with concentrations of soil $\mathrm{Al}^{3+}$, nitrogen, phosphorus and potassium. Concentrations of soil $\mathrm{Al}^{3+}$, nitrogen, phosphorus and potassium were all negatively correlated with shoot and root weight, root length, area and volume, plant height and branching number, whereas soil $\mathrm{pH}$ showed positive relationship with these parameters.

Table 3. Effects of $\mathrm{Al}^{3+}$ concentration and inoculation on nodule number, frequency of mycorrhiza ( $\mathrm{F} \%$ ), intensity of the mycorrhizal colonization (M\%) and arbuscular abundance (A\%) in Medicago sativa (alfalfa) and M.lupulina (black medick) grown in acid soils

\begin{tabular}{|c|c|c|c|c|c|c|c|c|c|}
\hline \multirow[b]{2}{*}{ Aluminum } & \multirow[b]{2}{*}{ Inoculation } & \multicolumn{2}{|c|}{ Nodule number } & \multicolumn{2}{|c|}{$\mathrm{F} \%$} & \multicolumn{2}{|c|}{$\mathrm{M} \%$} & \multicolumn{2}{|c|}{$\mathrm{A} \%$} \\
\hline & & Alfalfa & $\begin{array}{l}\text { Black } \\
\text { medick }\end{array}$ & Alfalfa & $\begin{array}{l}\text { Black } \\
\text { medick }\end{array}$ & Alfalfa & $\begin{array}{l}\text { Black } \\
\text { medick }\end{array}$ & Alfalfa & $\begin{array}{l}\text { Black } \\
\text { medick }\end{array}$ \\
\hline \multirow[t]{3}{*}{ Al1 } & $\mathrm{Rh}$ & $0.00 \pm 0.00 \mathrm{~b}$ & $0.00 \pm 0.00 \mathrm{~b}$ & - & - & - & - & - & - \\
\hline & $\mathrm{Rh}+\mathrm{AMF}$ & $12.00 \pm 2.45 \mathrm{a}$ & $2.25 \pm 0.63 \mathrm{a}$ & $82.07 \pm 2.44 \mathrm{a}$ & $74.07 \pm 4.09 \mathrm{a}$ & $16.45 \pm 0.95 \mathrm{a}$ & $2.51 \pm 0.88 \mathrm{a}$ & $6.66 \pm 1.40 \mathrm{a}$ & $0.40 \pm 0.26 \mathrm{a}$ \\
\hline & AMF & - & - & $63.54 \pm 2.78 \mathrm{~b}$ & $65.18 \pm 3.18 \mathrm{a}$ & $12.00 \pm 1.63 \mathrm{~b}$ & $2.19 \pm 0.36 \mathrm{a}$ & $2.07 \pm 0.33 b$ & $0.55 \pm 0.22 \mathrm{a}$ \\
\hline \multirow[t]{3}{*}{$\mathrm{A} 12$} & $\mathrm{Rh}$ & $2.50 \pm 0.20 \mathrm{~b}$ & $0.00 \pm 0.00 \mathrm{~b}$ & - & - & - & - & - & - \\
\hline & $\mathrm{Rh}+\mathrm{AMF}$ & $4.50 \pm 0.29 \mathrm{a}$ & $2.25 \pm 0.25 \mathrm{a}$ & $67.62 \pm 1.53 b$ & $75.56 \pm 3.57 \mathrm{a}$ & $2.14 \pm 0.41 \mathrm{~b}$ & $14.73 \pm 1.31 \mathrm{a}$ & $0.45 \pm 0.24 b$ & $1.21 \pm 0.03 \mathrm{a}$ \\
\hline & $\mathrm{AMF}$ & - & - & $87.34 \pm 0.27 \mathrm{a}$ & $82.96 \pm 3.18 \mathrm{a}$ & $6.02 \pm 0.78 \mathrm{a}$ & $4.67 \pm 1.02 b$ & $2.14 \pm 0.37 \mathrm{a}$ & $0.17 \pm 0.02 b$ \\
\hline \multirow[t]{3}{*}{$\mathrm{A} 13$} & $\mathrm{Rh}$ & $0.00 \pm 0.00$ & $0.00 \pm 0.00$ & - & - & - & - & - & - \\
\hline & $\mathrm{Rh}+\mathrm{AMF}$ & $0.00 \pm 0.00$ & $0.00 \pm 0.00$ & $92.22 \pm 0.45 \mathrm{a}$ & $87.29 \pm 2.95 \mathrm{a}$ & $2.53 \pm 0.53 b$ & $13.16 \pm 1.8 \mathrm{~b}$ & $0.49 \pm 0.15 b$ & $5.19 \pm 0.90 \mathrm{a}$ \\
\hline & AMF & - & - & $86.67 \pm 2.72 \mathrm{a}$ & $93.26 \pm 0.87 \mathrm{a}$ & $16.57 \pm 3.48 \mathrm{a}$ & $20.63 \pm 0.63 a$ & $7.31 \pm 1.51 \mathrm{a}$ & $5.69 \pm 1.17 \mathrm{a}$ \\
\hline \multicolumn{10}{|c|}{ Analysis of variance $(F)$} \\
\hline $\mathrm{Al}$ & & $17.80 * * *$ & $11.05 * * *$ & $37.35 * * *$ & $21.64 * * *$ & $18.47 * * *$ & $86.76 * * *$ & $7.15^{* * *}$ & $41.35 * * *$ \\
\hline Inoculation (I) & & $32.00 * * *$ & $44.18 * * *$ & $0.81 \mathrm{~ns}$ & $0.34 \mathrm{~ns}$ & $10.83 * * *$ & $1.17 \mathrm{~ns}$ & $3.37^{*}$ & $0.06 \mathrm{~ns}$ \\
\hline $\mathrm{Al} \times \mathrm{I}$ & & $20.25 * * *$ & $11.05 * * *$ & $47.97 * * *$ & $4.13 * *$ & $15.35 * * *$ & $31.63 * * *$ & $21.38 * * *$ & $0.85 \mathrm{~ns}$ \\
\hline
\end{tabular}

Note. Different small letters represented significance at $\mathrm{P}<0.05$ (LSD). Rh, rhizobia inoculation solely; AMF, AMF inoculation solely; Rh+AMF, co-inoculation with rhizobia and AMF.

Table 4. Correlation analysis among plant and soil parameters $(\mathrm{n}=96)$

\begin{tabular}{|c|c|c|c|c|c|c|c|c|c|c|c|c|c|c|c|}
\hline & Shoot & Root & $\mathrm{R} / \mathrm{S}$ & $\mathrm{H}$ & $\mathrm{Br}$ & $\mathrm{Rl}$ & $\mathrm{Ra}$ & $\mathrm{Rv}$ & $\mathrm{N}$ & $\mathrm{P}$ & $\mathrm{K}$ & $\mathrm{AN}$ & $\mathrm{AP}$ & $\mathrm{AK}$ & $\mathrm{pH}$ \\
\hline Shoot & 1.000 & & & & & & & & & & & & & & \\
\hline Root & $0.389 * *$ & 1.000 & & & & & & & & & & & & & \\
\hline $\mathrm{R} / \mathrm{S}$ & $-0.241^{*}$ & $0.757 * *$ & 1.000 & & & & & & & & & & & & \\
\hline $\mathrm{H}$ & $0.873 * *$ & $0.614 * *$ & 0.066 & 1.000 & & & & & & & & & & & \\
\hline $\mathrm{Br}$ & $0.928 * *$ & $0.208^{*}$ & $-0.400 * *$ & $0.781^{* *}$ & 1.000 & & & & & & & & & & \\
\hline $\mathrm{R} 1$ & $0.905^{* *}$ & $0.568 * *$ & 0.025 & $0.896^{* *}$ & $0.815 * *$ & 1.000 & & & & & & & & & \\
\hline $\mathrm{Ra}$ & $0.773^{* *}$ & $0.739 * *$ & $0.285^{* *}$ & $0.859 * *$ & $0.649 * *$ & $0.917 * *$ & 1.000 & & & & & & & & \\
\hline $\mathrm{Rv}$ & $0.510^{* *}$ & $0.763 * *$ & $0.477 * *$ & $0.682 * *$ & $0.366^{* *}$ & $0.684 * *$ & $0.905 * *$ & 1.000 & & & & & & & \\
\hline $\mathrm{N}$ & $-0.838 * *$ & $-0.414^{* *}$ & 0.143 & $-0.784 * *$ & $-0.804 * *$ & $-0.777 * *$ & $-0.691^{* *}$ & $-0.501 * *$ & 1.000 & & & & & & \\
\hline $\mathrm{P}$ & $-0.249 *$ & $0.316^{* *}$ & $0.490 * *$ & -0.031 & $-0.289 * *$ & -0.104 & 0.034 & 0.143 & $0.287^{* *}$ & 1.000 & & & & & \\
\hline $\mathrm{K}$ & $-0.244^{*}$ & $0.398 * *$ & $0.616^{* *}$ & 0.014 & $-0.331 * *$ & -0.065 & 0.106 & $0.244^{*}$ & $0.214^{*}$ & $0.735 * *$ & 1.000 & & & & \\
\hline $\mathrm{AN}$ & $-0.615^{* *}$ & $-0.450 * *$ & -0.056 & $-0.654 * *$ & $-0.625 * *$ & $-0.578 * *$ & $-0.595^{* *}$ & $-0.522^{* *}$ & $0.658^{* *}$ & -0.036 & -0.014 & 1.000 & & & \\
\hline AP & $-0.876^{* *}$ & $-0.586^{* *}$ & -0.075 & $-0.909 * *$ & $-0.781 * *$ & $-0.931 * *$ & $-0.886^{* *}$ & $-0.721 * *$ & $0.761 * *$ & 0.033 & -0.055 & $0.686^{* *}$ & 1.000 & & \\
\hline $\mathrm{AK}$ & $-0.728 * *$ & $-0.646^{* *}$ & -0.179 & $-0.817 * *$ & $-0.657 * *$ & $-0.764 * *$ & $-0.822 * *$ & $-0.773 * *$ & $0.666^{* *}$ & 0.034 & 0.071 & $0.719^{* *}$ & $0.820 * *$ & 1.000 & \\
\hline $\mathrm{pH}$ & $0.832 * *$ & $0.580 * *$ & 0.073 & $0.852 * *$ & $0.726^{* *}$ & $0.859 * *$ & $0.864 * *$ & $0.719^{* *}$ & $-0.660 * *$ & -0.147 & -0.095 & $-0.577 * *$ & $-0.868 * *$ & $-0.818 * *$ & 1.000 \\
\hline $\mathrm{Al}$ & $-0.881 * *$ & $-0.491 * *$ & 0.013 & $-0.870 * *$ & $-0.802 * *$ & $-0.895^{* *}$ & $-0.825 * *$ & $-0.634 * *$ & $0.727^{* *}$ & 0.063 & -0.005 & $0.648 * *$ & $0.945^{* *}$ & $0.745^{* *}$ & $-0.858 * *$ \\
\hline
\end{tabular}

Note. $* *$ represent significant at $\mathrm{P}<0.01 ; *$ represent significant at $\mathrm{P}<0.05$.

R/S, Root/shoot ratio; H, height; Br, branching number; Rl, root length; Ra, root surface area; Rv, root volume; $\mathrm{N}$, nitrogen content; $\mathrm{P}$; phosphorus content; $\mathrm{K}$, potassium content; AN, soil available nitrogen; AP, soil available phosphorus; AK, soil available potassium; $\mathrm{Al}$, soil $\mathrm{Al}^{3+}$. 


\section{Discussion and Conclusion}

Though both $\mathrm{Al}^{3+}$ concentrations and inoculation influenced plant growth parameters and concentrations of soil nutrients, $\mathrm{Al}^{3+}$ concentration had predominant effects over these parameters, showing significantly higher $\mathrm{F}$ value in two-way ANOVA analysis compared to that from inoculation. The effects of inoculation varied greatly among different $\mathrm{Al}^{3+}$ levels and showed significant interactions with $\mathrm{Al}^{3+}$ concentrations, suggesting that the efficiency of AMF inoculation in increasing legume yield in acid soils relying on initial soil $\mathrm{Al}^{3+}$ concentrations.

It is generally accepted that higher concentrations of soil $\mathrm{Al}^{3+}$ will result in abnormal growth of crops (Piñeros, Shaff, Manslank, Alves, \& Kochian, 2005; Valle, Carrasco, Pinochet, \& Calderini, 2009). In our study, plant height, branching number, shoot and root weight, and root growth all reduced with increased soil $\mathrm{Al}^{3+}$ concentrations. And a great decrease was observed when soil $\mathrm{Al}^{3+}$ concentration increased from $1000 \mathrm{mg} / \mathrm{kg}$ to $1100 \mathrm{mg} / \mathrm{kg}$, causing ca. $80 \%$ decrease in shoot weight and ca. $90 \%$ root weight for both alfalfa and black medick. This confirmed that both plant species were sensitive to high soil $\mathrm{Al}^{3+}$ concentrations, attributing to the limitations of high $\mathrm{Al}^{3+}$ concentration to root development, and thus the aboveground growth. In solutions with 0 , 2 and $4 \mathrm{mM} \mathrm{AlCl}_{3}$, the root length inhibition rates reached ca. $80 \%$ at $4 \mathrm{mM} \mathrm{Al}{ }^{3+}$ for alfalfa (Pan et al., 2008). In soils with $0.7 \mathrm{cmol} / \mathrm{kg} \mathrm{Al}^{3+}$, root weight reduced by $35 \%$ to $73 \%$ (differed among cultivars) compared to those in soils with $0.02 \mathrm{cmol} / \mathrm{kg} \mathrm{Al}^{3+}$ (Khu et al., 2012). Root weight of alfalfa exposed to $100 \mu \mathrm{M} \mathrm{AlCl}_{3} \mathrm{reduced} \mathrm{by}$ $56.1 \%$ than those in $0 \mu \mathrm{M} \mathrm{AlCl}$ (Wang, Ren, Huang, Wang, Zhou, \& An, 2016). In solutions with $2 \mathrm{mM}$ $\mathrm{AlCl}_{3}$ and $4 \mathrm{mM} \mathrm{AlCl}_{3}, 12$ from 13 alfalfa cultivars showed significant inhibition of biomass accumulation when compared to that in $0 \mathrm{mM} \mathrm{AlCl}_{3}$ (Pan et al., 2008).

Though plant growth was reduced in high $\mathrm{Al}^{3+}$ soils, the contents of nitrogen, phosphorus and potassium in alfalfa and medick showed an increase trend with increased $\mathrm{Al}^{3+}$ concentrations in the current study. For example, the nitrogen content increased $36.56 \%$ and $43.27 \%$ in alfalfa and black medick, respectively, when soil $\mathrm{Al}^{3+}$ concentration increased from $900 \mathrm{mg} / \mathrm{kg}$ to $1100 \mathrm{mg} / \mathrm{kg}$. Such increase, on one hand, implied that aluminum in soil stimulated nutrients uptake by alfalfa and black medick. Osaki, Watanabe and Tadano (1997) reported that the nitrogen, phosphorus and potassium in Al-tolerant plant species such as Melastoma malabathricum, Melaleuca cajuputi, Acacia mangium, Hydrangea macrophyila, Vaccinium macrocarpon, Polygonum sachalinense, and Oryza sativa, were stimulated by application of Al, whereas inhibited in Al-tolerant plant species such as Hordeum vulgare. Concentrations of nitrogen and potassium in leaves of montane forest tree seedlings increased significantly with increasing $\mathrm{Al}^{3+}$ concentrations (Rehmus, Bigalke, Valarezo, Castillo, \& Wilcke, 2015). Since legumes, such as alfalfa and black medick, are not regarded as Al tolerant species, other factors might be involved in regulating nutrients uptake from $\mathrm{Al}^{3+}$ rich soils. In this study, overall, an increase of soil available nitrogen, phosphorus and potassium were also observed with increased $\mathrm{Al}^{3+}$ concentrations. And the plant nitrogen content was positively correlated with the concentrations of soil $\mathrm{Al}^{3+}$, available nitrogen, phosphorus and potassium.

On the other hand, the $\mathrm{Al}^{3+}$ concentrations in this study were adjusted by adding lime. Lime application reduced soil $\mathrm{Al}^{3+}$ concentration and increased soil $\mathrm{pH}$ value whereas reduced the concentrations of soil available nitrogen. This was inconsistent with the results from most studies where lime was applied to improve soil nutrient availabilities (Barman, Shukla, Datta, \& Rattan, 2014; Brown, Koenig, Huggins, Harsh, \& Rossi, 2008; Sova, 1996). One possible reason for this inconsistency of the increase of plant nutrients and the decrease of plant growth with increased $\mathrm{Al}^{3+}$ concentrations might be related to the plant morphology or nutrient dilution effects (Jarrell \& Beverly, 1981). The plant growth was severely limited at $1100 \mathrm{mg} / \mathrm{kg} \mathrm{Al} \mathrm{j}^{3+}$, where more leaves rather than stems were relatively formed for small plants, resulting in relatively higher amounts of nitrogen content (He et al., 2015).

Though the efficiency of inoculation in improving plant growth was not as great as adjusting $\mathrm{Al}^{3+}$ concentrations did in acid soils, AMF inoculation did increase the shoot weight and root weight of both plant species under most circumstances, suggesting that it was also an alternative way in improving alfalfa growth in acid soils. This was consistent with the results from other similar studies (Guo, Ni, \& Huang, 2010; Yano $\&$ Takaki, 2005). However, unlike the single strain or mix of certain AMF inoculant used in these studies, the AMF spores used in the current study were isolated directly from soils growing black medick. In total five AMF strains, mainly Glomus species, were observed, suggesting that the AMF strains might have displayed synergistic or competitive behavior to increase colonization. The effectiveness of mycorrhizal colonization varied between the fungal isolates introduced (Orłowska, Ryszka, Jurkiewicz, \& Turnau, 2005). At a grassland mine restoration site, the use of local soil as an inoculum had greater effects on native and non-native plants than the commercial AMF inoculum used (Emam, 2016). However, it is difficult to determine the relative contribution of each AMF group to the colonization without the use of real-time PCR 
methods (Alkan, Gadkar, Yarden, \& Kapulnik, 2006; Jin, Germida, \& Walley, 2013). Anyway, the AMF spores isolated from black medick had high compatibility with alfalfa, showing high colonization and could be applied on alfalfa.

The effects of inoculation on root characteristics differed greatly among soil $\mathrm{Al}^{3+}$ concentrations and between plant species. For black medick, AMF inoculation improved root growth, benefiting their adaptations to acid soils. For alfalfa, AMF inoculation overall increased root growth at Al2 and Al3 but decreased at Al1. This was consistent with the changes of AMF colonization. A significant lower AMF colonization was also observed at Al1 compared to A12 and Al3 for alfalfa, suggesting that higher colonization might benefit alfalfa when growing in acid soils. Paudel, Baer and Battaglia (2014) reported that a higher degree of AMF colonization, relative to native co-occurring species, might partly explain the successful invasion of Triadica sebifera into coastal plant communities of the southeastern USA. However, a significant lower shoot and root weight at Al3 compared to All and Al2 implied that AMF colonization might be not related to dry matter yield, mainly related to the difference of dominant AMF strains at different soil $\mathrm{Al}^{3+}$ concentrations. Clark (1997) found that maximum enhancement of plant growth in acid soil varied with AMF isolate and soil $\mathrm{pH}$, indicating adaptation of AM isolates to edaphic conditions. Long-term lime application changed soil nutrient availability and increased AMF colonization, but decreased AMF phylotype diversity, implying that soil chemical properties may determine the distribution of AMF in acid soils (Guo et al., 2012). The higher AMF colonization at Al3 compared to Al1 might also be related to the soil available phosphorus concentrations. Soil available phosphorus concentrations increased with increased $\mathrm{Al}^{3+}$ concentrations, thus influencing the AMF colonization. Zhang, Wang, Ma, Zhang and $\mathrm{Fu}$ (2016) also reported that greater colonization of roots by AMF was possibly achieved with inoculating AMF isolate in soils with high $\mathrm{P}$ availability.

The main function of AMF colonization has been shown to be their effects on nutrient uptake from infertile soils (Smith \& Read, 1997). In the current study, the AMF inoculation had more influence on phosphorus content rather than nitrogen and potassium contents. Overall, AMF colonization and dual colonization with rhizobia had a trend in increasing the contents of phosphorus in both plant species at all $\mathrm{Al}^{3+}$ concentrations. This was very important for these legumes growing in acid soils where soil phosphorus was generally a limiting factors (Tchienkoua \& Zech, 2010), mainly attributing to the enlargement of the phosphorus adsorbing surface of the plant by the AMF hyphae (Li, Marschner, \& George, 1991). Another important role of AMF inoculation in acid soils might be in conferring Al resistance to their host plants through Al-P interactions (Seguel, Cumming, Klugh-Stewart, Cornejo, \& Borie, 2013), increasing plant tolerance to high levels of Al, and thereby improving nutrient acquisition (Lux \& Cumming, 2001). In the current study, higher AMF colonization was observed at all $\mathrm{Al}^{3+}$ levels, showing high Al tolerance for these isolated AMF spores. Furthermore, AMF inoculation also influenced the concentrations of soil $\mathrm{Al}^{3+}$, available nitrogen, phosphorus and potassium. However, no consistency could be observed between two plant species and among $\mathrm{Al}^{3+}$ concentrations except that AMF solely and dual inoculation increased soil $\mathrm{Al}^{3+}$ for two plant species at $\mathrm{Al}$. This implied that AMF colonization improved the plant growth in acid soils mainly through enlarging nutrient adsorbing area but not by altering the availability of soil nutrients.

Formations of nodules are very important for legumes, particularly in low fertility soils. In the current study, no nodule was observed in two plant species at all $\mathrm{Al}^{3+}$ concentrations except for alfalfa at $\mathrm{Al} 2$, when rhizobia was inoculated solely. This implied that factors other than soil $\mathrm{Al}^{3+}$ and $\mathrm{pH}$ might also limit the nodulation, particularly minerals such as Mo and Co (Rosolem \& Caires, 2000; Leite, Araújo, Costa, \& Ribeiro, 2009), the availabilities of which might also be limited in acid soils or influenced by lime application (Mandai, Pal, \& Mandai, 1998). However, dual inoculation significantly increased nodulation ability and both plant species formed nodule at Al1 and A12, suggesting that the formation of mycorrhizae by AMF improved nodulation for legumes growing in acid soils. This might also be attributed to the improvement of mineral adsorptions by AMF hyphae in acid soils. Meanwhile, dual inoculation increased AMF colonization (the intensity of the mycorrhizal colonization, $\mathrm{M} \%$ ) in alfalfa at Al1, reduced in alfalfa but increased in black medick at A12, and reduced for both plant species at Al3. This implied that rhizobia and AMF might have competition when colonizing plant roots together. In a root-split experiment with alfalfa, Callaway et al. (2003) reported that nodulation systemically influenced AMF root colonization. The variations in AMF colonization when co-inoculated with rhizobia under different $\mathrm{Al}^{3+}$ concentrations might also be attributed to the difference of dominant AMF strains colonized at different soil $\mathrm{Al}^{3+}$ concentrations as discussed above. 


\section{Conclusion}

Soil $\mathrm{Al}^{3+}$ concentrations significantly limited plant above- and below-ground growth for both alfalfa and black medick. Though the efficiency of AMF inoculation in increasing plant growth was less than that of adjusting $\mathrm{Al}^{3+}$ concentrations, AMF inoculation increased the shoot and root weight of both plant species under most circumstances and improved nodulation ability, suggesting that it was also an alternative way in improving alfalfa growth in acid soils. However, soil $\mathrm{Al}^{3+}$ concentrations influenced the efficiency of AMF in promoting alfalfa growth in acid soils. The AMF inoculant used in current study was a mixture from several strains. Further study is needed to clarify the functions of each AMF strain in improving alfalfa growth in high $\mathrm{Al}^{3+}$ acid soils.

\section{References}

Alkan, N., Gadkar, V., Yarden, O., \& Kapulnik, Y. (2006). Analysis of quantitative interactions between two species of arbuscular mycorrhizal fungi, Glomus mosseae and G. intraradices, by real-time PCR. Appl Environ Microbiol, 72, 4192-4199. https://doi.org/10.1128/AEM.02889-05

Bao, S. D. (2005). Agricultural chemical analysis of soil. Beijing: China Agriculture Press.

Barman, M., Shukla, L. M., Datta, S. P., \& Rattan, R. K. (2014). Effect of applied lime and boron on the availability of nutrients in an acid soil. J Plant Nutr, 37, 357-373. https://doi.org/10.1080/01904167. 2013.859698

Brown, T. T., Koenig, R. T., Huggins, D. R., Harsh, J. B., \& Rossi, R. E. (2008). Lime effects on soil acidity, crop yield, and aluminum chemistry in direct-seeded cropping systems. Soil Sci Soc Am J, 72, 634-640. https://doi.org/10.2136/sssaj2007.0061

Cai, D., Xiao, W., \& Li, G. (2010). Advance on study of liming on acid soils. Chinese Agricultural Science Bulletin, 26(9), 206-213.

Callaway, R. M., Mahall, B. E., Wicks, C., Pankey, J., \& Zabinski, C. (2003). Soil fungi and the effects of an invasive forb on grasses. neighbor identity matters. Ecology, 84, 129-135. https://doi.org/10.1890/ 0012-9658(2003)084[0129:SFATEO]2.0.CO;2

Castilhos, G., Farias, J. G., Schneider, A. D. B., Oliveira, P. H. D., Nicoloso, F. T., Schetinger, M. R. C., \& Delatorre, C. A. (2011). Aluminum-stress response in oat genotypes with monogenic tolerance. Environ Exp Bot, 74, 114-121. https://doi.org/10.1016/j.envexpbot.2011.05.007

Catford, J. G., Staehelin, C., Lerat, S., Piché, Y., \& Vierheilig, H. (2003). Suppression of arbuscular mycorrhizal colonization and nodulation in split-root systems of alfalfa after pre-inoculation and treatment with Nod factors. J Exp Bot, 54, 1481-1487. https://doi.org/10.1093/jxb/erg 156

Cavallazzi, J. R. P., Filho, O. K., Stürmer, S. L., Rygiewicz, P. T., \& Mendonça, M. M. D. (2007). Screening and selecting arbuscular mycorrhizal fungi for inoculating micropropagated apple rootstocks in acid soils. Plant Cell, Tissue and Organ Culture (PCTOC), 90, 117-129. https://doi.org/10.1007/s11240-006-9163-6

Choudhary, A. K., Singh, D., \& Iquebal, M. A. (2011). Selection of pigeonpea genotypes for tolerance to aluminium toxicity. Plant Breeding, 130, 492-495. https://doi.org/10.1111/j.1439-0523.2010.01833.x

Clark, R. B. (1997). Arbuscular mycorrhizal adaptation, spore germination, root colonization, and host plant growth and mineral acquisition at low pH. Plant Soil, 192, 15-22. https://doi.org/10.1023/A:100421 8915413

Clarkson, D. T. (1985). Factors affecting mineral nutrient acquisition by plants. Plant Biol, 137, 371-373. https://doi.org/10.1146/annurev.pp.36.060185.000453

Crusciol, C. A. C., Marques, R. R., Filho, A. C. A. C., Soratto, R. P., Costa, C. H. M., Neto, J. F., ... Castilhos, A. M. D. (2016). Annual crop rotation of tropical pastures with no-till soil as affected by lime surface application. Eur J Agron, 80, 88-104. https://doi.org/10.1016/j.eja.2016.07.002

Cumming, J. R., \& Ning, J. (2003). Arbuscular mycorrhizal fungi enhance aluminium resistance of broomsedge (Andropogon virginicus L.). J Exp Bot, 54, 1447-59. https://doi.org/10.1093/jxb/erg149

Denton, M. D., Coventry, D. R., Bellotti, W. D., \& Howieson, J. G. (2000). Distribution, abundance and symbiotic effectiveness of Rhizobium leguminosarum cv. trifolii from alkaline pasture soils in South Australia. Animal Production Science, 40, 25-35. https://doi.org/10.1071/EA99035 
Edmeades, D. R., \& Ridley, A. M. (2003). Using lime to ameliorate topsoil and subsoil acidity. In Z. Rengel (Ed.), Handbook of Soil Acidity (pp. 297-336). New York: Marcel Dekker Inc. https://doi.org/10.1201/ 9780203912317.ch11

Emam, T. (2016). Local soil, but not commercial AMF inoculum, increases native and non-native grass growth at a mine restoration site. Restor Ecol, 24, 35-44. https://doi.org/10.1111/rec.12287

Foy, C. D. (1988). Plant adaptation to acid, aluminum-toxic soils. Commun Soil Sci Plant Anal, 19, 959-987. https://doi.org/10.1080/00103628809367988

Fritz, O., Endre, L., Arno, B., Kari, S., Robert, B., Marcelvander, H., \& Ewald, S. (2010). Soil type and land use intensity determine the composition of arbuscular mycorrhizal fungal communities. Soil Biol Biochem, 42, 724-738. https://doi.org/10.1016/j.soilbio.2010.01.006

Grewal, H. S., \& Williams, R. (2003). Liming and cultivars affect root growth, nodulation, leaf to stem ratio, herbage yield, and elemental composition of alfalfa on an acid soil. J Plant Nutr, 26, 1683-1696. https://doi.org/10.1081/PLN-120022381

Guo, Y. J., Ni, Y., Yuan, L., \& Huang, J. G. (2009). Effects of liming and Sinorhizobium inoculation on growth, nodulation and nutrient concentrations of lucerne in acid soil. Tropical Grasslands, 43, 112-117.

Guo, Y. J., Ni, Y., \& Huang, J. G. (2010). Effects of rhizobium, arbuscular mycorrhiza and lime on nodulation, growth and nutrient uptake of lucerne in acid purplish soil in China. Tropical Grasslands, 44, 109-114.

Guo, Y. J., Ni, Y., Raman, H., Wilson, B. A. L., Ash, G. J., Wang, A. S, \& Li, G. D. (2012). Arbuscular mycorrhizal fungal diversity in perennial pastures; responses to long-term lime application. Plant Soil, 351, 389-403. https://doi.org/10.1007/s11104-011-0976-7

He, M., Zhang, K., Tan, H., Hu, R., Su, J., Wang, J., ... Li, X. (2015). Nutrient levels within leaves, stems, and roots of the xeric species Reaumuria soongorica in relation to geographical, climatic, and soil conditions. Ecol Evolution, 5, 1494-1503. https://doi.org/10.1002/ece3.1441

Heijne, B., Dam, D. V., Heil, G. W., \& Bobbink, R. (1996). Acidification effects on vesicular-arbuscular mycorrhizal (VAM) infection, growth and nutrient uptake of established heathland herb species. Plant Soil, 179, 197-206. https://doi.org/10.1007/BF00009329

Jan, F. (1991). Aluminium effects on growth, nutrient net uptake and transport in 3 rice (Oryza sativa) cultivars with different sensitivity to aluminium. Physiologia Plantarum, 83, 441-448. https://doi.org/10.1111/ j.1399-3054.1991.tb00118.x

Jarrell, W. M., \& Beverly, R. B. (1981). The dilution effect in plant nutrition studies. In N. C. Brady (Ed.), Advances in Agronomy (pp. 197-224). Academic Press. https://doi.org/10.1016/s0065-2113(08)60887-1

Jin, H., Germida, J. J., \& Walley, F. L. (2013). Impact of arbuscular mycorrhizal fungal inoculants on subsequent arbuscular mycorrhizal fungi colonization in pot-cultured field pea (Pisum sativum L.). Mycorrhiza, 23, 45-59. https://doi.org/10.1007/s00572-012-0448-9

Khu, D. M., Reyno, R., Brummer, E. C., \& Monteros, M. J. (2012). Screening methods for aluminum tolerance in alfalfa. Crop Science, 52, 161-167. https://doi.org/10.2135/cropsci2011.05.0256

Kochian, L. V., Piñeros, M. A., \& Hoekenga, O. A. (2004). The physiology, genetics and molecular biology of plant aluminum resistance and toxicity (pp. 175-195). Springer Netherlands.

Langer, H., Cea, M., Curaqueo, G., \& Borie, F. (2009). Influence of aluminum on the growth and organic acid exudation in alfalfa cultivars grown in nutrient solution. J Plant Nutr, 32, 618-628. https://doi.org/10.1080/ 01904160802715430

Li, X. L., Marschner, H., \& George, E. (1991). Acquisition of phosphorus and copper by VA-mycorrhizal hyphae and root-to-shoot transport in white clover. Plant Soil, 136, 49-57. https://doi.org/10.1007/ BF02465219

Leite, L. F. C., Araújo, A. S. F. D., Costa C. D. N., \& Ribeiro A. M. B. (2009). Nodulation and grain yield of cowpea in response to molybdenum. Revista Ciência Agronômica, 40(4), 492-497.

Lux, H. B., \& Cumming, J. R. (2001). Mycorrhizae confer aluminum resistance to tulip-poplar seedlings. Can J Forest Res, 31, 694-702. https://doi.org/10.1139/x01-004 
Macklon, A. E. S., Lumsdon, D. G., \& Sim, A. (1994). Phosphate uptake and transport in Agrostis capillaris L.: Effects of non-toxic levels of aluminium and the significance of $\mathrm{P}$ and $\mathrm{Al}$ speciation. $J$ Exp Bot, 45, 887-894. https://doi.org/10.1093/jxb/45.7.887

Mandai, B., Pal, S., \& Mandai, L. N. (1998). Effect of molybdenum, phosphorus, and lime application to acid soils on dry matter yield and molybdenum nutrition of lentil. $J$ Plant Nutr, 21, 139-147. https://doi.org/10.1080/01904169809365388

Martens, D. A. (2001). Nitrogen cycling under different soil management systems. Adv Agron, 70, 143-192. https://doi.org/10.1016/S0065-2113(01)70005-3

Nawrot, M., Szarejko, I., \& Maluszynski, M. (2001). Barley mutants with increased tolerance to aluminium toxicity. Euphytica, 120, 345-356. https://doi.org/10.1023/A:1017565121835

Olsen, S., \& Sommers, L. (1982). Phosphorus. In A. Page, R. Miller, \& D. Keeney (Eds.), Methods of Soil Analyses (Part 2), Chemical and Microbiological Properties (pp. 403-430). Madison, WI., USA: American Society of Agronomy.

Orłowska, E., Ryszka, P., Jurkiewicz, A., \& Turnau, K. (2005). Effectiveness of arbuscular mycorrhizal (AMF) strains in mycorrhizal colonisation of plants involved in phytostabilisation of zinc wastes. Geoderma, 129, 92-98. https://doi.org/10.1016/j.geoderma.2004.12.036

Osaki, M., Watanabe, T., \& Tadano, T. (1997). Beneficial effect of aluminum on growth of plants adapted to low pH soils. Soil Sci Plant Nutr, 43, 551-563. https://doi.org/10.1080/00380768.1997.10414782

Pan. X. B., Zhu, C., \& Cheng, C. (2008). Assessment of techniques for screening alfalfa cultivars for aluminum tolerance. Euphytica, 164, 541-549. https://doi.org/10.1007/s10681-008-9751-0

Paudel, S., Baer, S. G., \& Battaglia, L. L. (2014). Arbuscular mycorrhizal fungi (AMF) and success of Triadica sebifera invasion in coastal transition ecosystems along the northern Gulf of Mexico. Plant Soil, 378, 337-349. https://doi.org/10.1007/s11104-014-2026-8

Piñeros, M. A., Shaff, J. E., Manslank, H.S., Alves, V. M., \& Kochian, L. V. (2005). Aluminum resistance in maize cannot be solely explained by root organic acid exudation. A comparative physiological study. Plant Physiol, 137, 231-41. https://doi.org/10.1104/pp.104.047357

Qiu, G. (1989). Spectrophotometric determination of activated aluminium in soil using eriochrome cyanine R. Journal of Instrumental Analysis, 8(4), 68-71.

Rehmus, A., Bigalke, M., Valarezo, C., Castillo, J. M., \& Wilcke, W. (2015). Aluminum toxicity to tropical montane forest tree seedlings in southern Ecuador: Response of biomass and plant morphology to elevated Al concentrations. Plant Soil, 388, 87-97. https://doi.org/10.1007/s11104-014-2110-0

Rosolem, C. A., \& Caires, E. F. (2000). Nodulation and nitrogen uptake by peanut as affected by lime, cobalt, and molybdenum. Scientia Agricola, 57, 337-341. https://doi.org/10.1080/01904169809365446

Rouphael, Y., Cardarelli, M., \& Colla, G. (2015). Role of arbuscular mycorrhizal fungi in alleviating the adverse effects of acidity and aluminium toxicity in zucchini squash. Scientia Horticulturae, 188, 97-105. https://doi.org/10.1016/j.scienta.2015.03.031

Ryan, P. R., \& Delhaize, E. (2010). The convergent evolution of aluminium resistance in plants exploits a convenient currency. Functional Plant Biology, 37, 275-284. https://doi.org/10.1071/FP09261

Seguel, A., Cumming, J. R., Klugh-Stewart, K., Cornejo, P., \& Borie, F. (2013). The role of arbuscular mycorrhizas in decreasing aluminium phytotoxicity in acidic soils: A review. Mycorrhiza, 23, 167-183. https://doi.org/10.1007/s00572-013-0479-x

Shen, Y., Jiang, H., Zhai, G., \& Cai, Q. (2013). Effects of cutting height on shoot regrowth and forage yield of alfalfa (Medicago sativa L.) in a short-term cultivation system. Grassland Sci, 59, 73-79. https://doi.org/10.1111/grs.12014

Shi, R., Li, J., Xu, R., \& Qian, W. (2016). Ameliorating effects of individual and combined application of biomass ash, bone meal and alkaline slag on acid soils. Soil \& Tillage Research, 162, 41-45. https://doi.org/10.1016/j.still.2016.04.017

Smith, S., \& Read, D. (1997). Mycorrhizal symbiosis. London: Academic Press.

Sova, V. (1996). The influence of lime application to the acid soil on bioavailability of phosphorus in runoff. Water Sci Technol, 33, 297-301. https://doi.org/10.1016/0273-1223(96)00244-2 
Stenberg, M., Stenberg, B., \& Rydberg, T. (2000). Effects of reduced tillage and liming on microbial activity and soil properties in a weakly-structured soil. Appl Soil Ecol, 14, 135-145. https://doi.org/10.1016/S0929-1393 (00)00043-3

Talor, G. J. (1988). The Physiology of Aluminum Phytotoxicity. In H. Sigel, \& A. Sigel (Eds.), Metal Ions in Biological Systems (pp. 123-163). New York: Dekker.

Tchienkoua, T., \& Zech, W. (2010). Relationship of soil phosphorus pools with bray 1 phosphorus in some acid soils of central southern Cameroon. Commun Soil Sci Plant Anal, 41, 1327-1337. https://doi.org/10.1080/00103621003759338

Thompson, G. W., \& Medve, R. J. (1984). Effects of aluminum and manganese on the growth of ectomycorrhizal fungi. Appl Environ Microbiol, 48, 556-560.

Trouvelot, A., Kough, J., \& Gianinazzi-Pearson, V. (1986). Mesure du taux de mycorhization VA d'un système radiculaire. Recherche de méthodes d'estimation ayant une signification fonctionnelle. In $V$. Gianinazzi-Pearson, \& S. Gianinazzi (Eds.), Physiological and Genetical Aspects of Mycorrhizae (pp. 217-221). Paris: INRA Press.

Turmel, M. (2007). The effect of a long-term black medic (Medicago lupulina) cover crop on arbuscular mycorrhizal fungi colonization and nutrient uptake of flax (Linum usitatissimum). University of Manitoba, Winnipeg, Manitoba.

Undersander, D., Martin, N., Cosgrove, D., Kelling, K., Schmitt, M., Wedberg, J., ... Doll, J. (1991). Alfalfa management guide. North Central Regional Extension Publication, 47, 343-344.

Valle, S. R., Carrasco, J., Pinochet, D., \& Calderini, D. F. (2009). Grain yield, above-ground and root biomass of Al-tolerant and Al-sensitive wheat cultivars under different soil aluminum concentrations at field conditions. Plant Soil, 318, 299-310. https://doi.org/10.1007/s11104-008-9841-8

Vandamme, E., Renkens, M., Pypers, P., Smolders, E., Vanlauwe, B., \& Merckx, R. (2013). Root hairs explain P uptake efficiency of soybean genotypes grown in a P-deficient Ferralsol. Plant Soil, 369, 269-282. https://doi.org/10.1007/s11104-012-1571-2

Walker, R. F. (2002). Growth and nutritional responses of bareroot Jeffrey pine on a Sierra Nevada surface mine to minisite applications of fertilizer and lime. New Forests, 24, 225-238. https://doi.org/10.1023/ A:1021337321332

Wang, S., Ren, X., Huang, B., Wang, G., Zhou, P., \& An, Y. (2016). Aluminium-induced reduction of plant growth in alfalfa (Medicago sativa) is mediated by interrupting auxin transport and accumulation in roots. Scientific Reports, 6, 30079. https://doi.org/10.1038/srep30079

Whelan, A. M., \& Alexander, M. (1986). Effects of low pH and high Al, Mn and Fe levels on the survival of Rhizobium trifolii and the nodulation of subterranean clover. Plant Soil, 92, 363-371. https://doi.org/10.1007/BF02372484

Xiao, X., Yang, Z., Xiao, H., \& Xie, Y. (2003). Effect of aluminum stress on active oxygen metabolism and membrane system of longan (Dimocaepus longan) leaves. Scientia Silvae Sinicae, 39, 52-57.

Yan. J., Chu, H. J., Wang, H. C., Li, J. Q., \& Sang, T. (2009). Population genetic structure of two Medicago species shaped by distinct life form, mating system and seed dispersal. Annal Bot, 103, 825-34. https://doi.org/10.1093/aob/mcp006

Yano, K., \& Takaki, M. (2005). Mycorrhizal alleviation of acid soil stress in the sweet potato (Ipomoea batatas ). Soil Biol Biochem, 37, 1569-1572. https://doi.org/10.1016/j.soilbio.2005.01.010

Yurkova, A. P., Jacobi, L. M., Gapeeva, N. E., Stepanova, G. V., \& Shishova, M. F. (2015). Development of arbuscular mycorrhiza in highly responsive and mycotrophic host plant-black medick (Medicago lupulina L.). Russian Journal of Developmental Biology, 46, 263-275. https://doi.org/10.1134/S1062360415050082

Zhang, S., Wang, L., Ma, F., Zhang, X., \& Fu, D. (2016). Arbuscular mycorrhiza improved phosphorus efficiency in paddy fields. Ecol Eng, 95, 64-72. https://doi.org/10.1016/j.ecoleng.2016.06.029

Zhao, Z. W., Xia, Y. M., Qin, X. Z., Li, X. W., Cheng, L. Z., Sha, T., \& Wang, G. H. (2001). Arbuscular mycorrhizal status of plants and the spore density of arbuscular mycorrhizal fungi in the tropical rain forest of Xishuangbanna, southwest China. Mycorrhiza, 11, 159-162. https://doi.org/10.1007/s005720100117 


\section{Copyrights}

Copyright for this article is retained by the author(s), with first publication rights granted to the journal.

This is an open-access article distributed under the terms and conditions of the Creative Commons Attribution license (http://creativecommons.org/licenses/by/4.0/). 